\title{
What moves international stock and bond markets?*
}

\author{
Gino Cenedese $^{\dagger} \quad$ Enrico Mallucci ${ }^{\ddagger}$
}

This draft: June 2015

\begin{abstract}
We study the relation between international mutual fund flows and the different return components of aggregate equity and bond markets. First, we decompose international equity and bond market returns into changes in expectations of future real cash payments, interest rates, exchange rates, and discount rates. News about future cash flows, rather than discount rates, is the main driver of international stock returns. This evidence is in contrast with the typical results reported only for the US. Inflation news instead is the main driver of international bond returns. Next, we turn to the interaction between these return components and international portfolio flows. We find evidence consistent with price pressure, short-term trend chasing, and short-run overreaction in the equity market. We also find that international bond flows to emerging markets are more sensitive to interest rate shocks than equity flows.
\end{abstract}

JEL classification: F31, G15.

Keywords: International Capital Flows, Return Decomposition, International Equity Markets, International Bond Markets, Mutual Funds.

${ }^{*}$ Acknowledgements: This paper is now forthcoming in the Journal of International Money and Finance. We would like to thank for useful comments Kees Koedijk (editor), an anonymous referee, Gaston Gelos, Bob Hills, Kate Phylaktis, Dagfinn Rime, Andrea Serafino, Matthew Willison, and participants to the 4th EMG-ECB Conference at Cass Business School. The views expressed in this paper are those of the authors, and not necessarily those of the Bank of England.

${ }^{\dagger}$ Bank of England, Threadneedle Street, London EC2R 8AH, United Kingdom. E-mail: gino.cenedese@bankofengland.co.uk (corresponding author).

${ }_{\ddagger}^{\ddagger}$ London School of Economics. E-mail: e.mallucci@lse.ac.uk. 


\section{Introduction}

The increased magnitude and volatility of cross-border capital flows have been a distinguishing feature of financial globalisation over the last two decades. The composition of these flows has also changed. International mutual funds play an increasingly important role in the landscape of international investment. These funds are progressively entering localcurrency bond markets, and bond flows have increased their importance relative to equity flows and cross-border bank lending (International Monetary Fund, 2014).

The expanding size of the international mutual funds industry, together with its procyclical behaviour during crises and its role in the international transmission of shocks (Jotikasthira, Lundblad, and Ramadorai, 2012; Raddatz and Schmukler, 2012), have recently attracted the interest of policymakers because of the associated risks for financial stability (Haldane, 2014). Therefore, the study of the behaviour of international mutual funds can inform policymakers on both the optimal policy for managing capital flows and the reform of the international monetary system more broadly. While there has been a considerable debate about the relationship between international (mostly equity) portfolio flows and as-

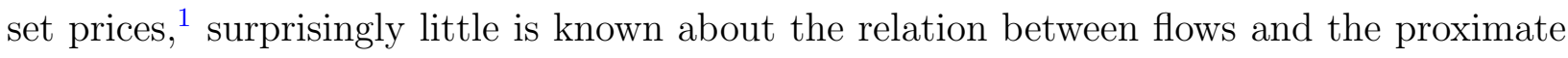
drivers of these asset prices, such as news about discount rates and expected cash flows. This paper tries to fill this gap in the literature. First, we decompose international equity and bond market returns into changes in expectations of future dividends, inflation, interest rates, exchange rates, and discount rates, and study their relative importance in driving unexpected returns. Second, we analyse how these different components are associated with international mutual fund flows.

Our work is related to two literatures. First, there is an important literature that studies the joint dynamics of international capital flows and equity returns. A seminal paper is Bohn and Tesar (1996): they find that foreign investors are "return chasers," i.e. they

\footnotetext{
${ }^{1}$ See, e.g., Bohn and Tesar (1996); Froot, O'Connell, and Seasholes (2001); Froot and Ramadorai (2008); Jotikasthira et al. (2012); Raddatz and Schmukler (2012).
} 
provide evidence that foreign investors react to changes in expected returns. There are two related aspects of the trading behaviour of money managers: herding, i.e. the tendency of a group of managers to trade in the same direction; and momentum trading (also called positive-feedback trading), ie. buying past winners and selling past losers. Both aspects have been initially studied in the US market by Lakonishok, Shleifer, and Vishny (1992). A number of recent papers (Froot et al., 2001; Froot and Ramadorai, 2008; Jotikasthira et al., 2012; Raddatz and Schmukler, 2012) find evidence for international funds that is consistent with this behaviour. Another view focuses on the impact of flows on returns. For example, Froot et al. (2001) find that equity inflows have a positive impact on stock market returns. Jotikasthira et al. (2012) show that international mutual funds' portfolio reallocations have a significant price effect. The increase in price due to inflows may be temporary, reflecting "price pressure," or permanent, such as in the case of information-driven flows (Kyle, 1985). Lou (2012) finds that flow-driven trading by mutual funds can explain return predictability, price pressure, and stock price momentum.

Our paper is also related to a second literature on empirical asset pricing. Mainstream research in empirical asset pricing asserts that discount-rate variation is its "central organizing question" (Cochrane, 2011). ${ }^{2}$ This conclusion stems from the finding, mostly reported for the US equity market, that expected return shocks account for most of the variation of asset price returns, with little role for variation in expected cash flows. ${ }^{3}$ However, a number of recent papers find more ambiguous results about the relative size of these two components. For example, Vuolteenaho (2002) finds that the cash-flow component always prevails when studying firm-level stock returns in the US. Phylaktis and Ravazzolo (2002), concentrating on a sample of countries in the Pacific-Basin region, find that the cash-flow shock component prevails over the expected-return component. More recently, Plazzi (2010)

\footnotetext{
${ }^{2}$ As in Cochrane (2011), in this paper we use the terms "discount rate," "risk premium," and "expected return" interchangeably.

${ }^{3}$ See also Cochrane (2008); Van Binsbergen and Koijen (2010); Koijen and Nieuwerburgh (2011) for the evidence on US aggregate stock market, Ang and Bekaert (2007) for the evidence on a small number of advanced economies, and Plazzi, Torous, and Valkanov (2010) for the evidence on US commercial real estate.
} 
finds that expected return shocks prevail over cash-flow shocks in the US, while the opposite is true in the UK. Rangvid, Schmeling, and Schrimpf (2013) find that in a large number of non-US countries, dividend growth is predictable using the dividend yield as a predictor, which they interpret as evidence that news about future dividends is the main driver of return innovations.

We contribute to the two strands of the literature in three ways. First, we extend the analysis to 31 countries, including 18 advanced economies and 13 emerging markets. Second, we analyse both stock and bond markets in all these countries. With few exceptions, the literature has focused on the equity market. By looking at the bond market, we extend the analysis to a large share of global capital markets that has been perhaps under-represented in earlier studies. Third, we study the interaction between the return components and international portfolio flows.

We decompose the innovations in international asset returns into revisions in expectations of future real cash payments to investors, real interest rates, exchange rates, and discount rates. We find that news about future real cash payments is the main source of variation for bond and equity excess returns. Importantly, our findings are at odds with the evidence commonly found in the literature, reported mostly for the US equity market, that asset price movements are mainly due to innovations in expected returns, or equivalently to discount rate variation (e.g., Cochrane, 2011). News about exchange rate changes and real interest rate changes contributes little, if anything, to the variance of unexpected equity returns. This finding is consistent with that of Ammer and Mei (1996) and Phylaktis and Ravazzolo (2002) and it is also in line with the results of the cross-sectional asset pricing exercise of Cenedese, Payne, Sarno, and Valente (2015), who find that returns on international equity markets are broadly unrelated to exchange rates.

Next, we explore the interaction between these return components and international portfolio flows. When markets are fully rational and complete and there are no information asymmetries nor any restrictions on capital movements, the relation between international 
portfolio flows and asset returns is of little interest. Returns react to changes in fundamentals and flows simply adjust to the new returns. On this basis, traditional macro models have largely neglected flows and concentrated on returns instead, and generally assume there is only contemporaneous relation between capital flows and asset returns.

A number of papers, however, have shown the existence of significant non-contemporaneous correlation between flows and returns. Using equity flow data for a large custodian bank, Froot et al. (2001) find that flows are affected by past returns and that inflows forecast future equity returns in emerging markets. Using similar data for the foreign exchange market, Froot and Ramadorai (2005) study the correlation between foreign exchange flows and currency returns and find that the contemporaneous correlation between flows and returns varies when it is calculated over different time horizons. They interpret this finding as evidence that either flows predict returns or vice-versa, or both. To the best of our knowledge, our paper is the first one to study the non-contemporaneous relation between portfolio flows and the proximate drivers of asset returns in the context of international equity and bond markets.

When return shocks are driven by cash-flow news, we find evidence of a short-term trend chasing pattern in the equity market. In the long run, instead, cash-flow news is associated with equity outflows. As Froot and Ramadorai (2005) note, if investors trendchase mechanically, we should observe an inflow after an appreciation of asset prices, even when this appreciation is temporary as implied by a fall in the discount rates. To test for mechanical trend chasing, we evaluate investors' response to a negative discount rate shock, keeping the other news components constant. ${ }^{4}$ We find that negative discount rate shocks predict equity outflows. International investors respond to a short-term transitory appreciation (i.e. a negative discount rate shock) by selling and to a permanent appreciation (i.e. a cash-flow shock) by buying. This evidence is stronger for institutional investors relative to retail investors, as for the latter group the results are not statistically significant. Real

\footnotetext{
${ }^{4}$ Remember that, holding the other components constant, a fall in expected future returns may be achieved only through an increase in today's returns.
} 
interest rate shocks and exchange rate shocks are not associated with equity flows.

Contrary to what we observe in the equity market, bond flows toward emerging economies are influenced by US real interest rate shocks. An upward revision of US interest rate expectations is associated with bond outflows in the short run. This result appears consistent with the view that debt flows to emerging markets are strongly correlated with policy interventions and the business cycle of developed economies; see, e.g., Ahmed and Zlate (2013). Discount rates shocks, inflation shocks, and exchange rates shocks instead are not associated with bond flows.

The rest of the paper is organised as follows: Section 2 describes the empirical methodology. Section 3 describes our database. Section 4 describes and comments on our empirical results. Section 5 concludes.

\section{Empirical Methodology}

\subsection{International Equity Return Decomposition}

Our analysis aims at studying the relation between capital flows and asset excess returns. A first step in this direction is to understand the dynamics that govern excess return movements. Campbell (1991) proposes an approximate present-value identity and shows how that equity return shocks can be decomposed into cash-flow shocks and expected-return shocks. An unexpected increase in excess returns today can be due to an increase in expected future cash flows (dividends), a downward revision of expected future excess returns (equivalently, a fall in risk premia), or both.

Ammer and Mei (1996) extend the Campbell (1991) decomposition to an international setting. We follow their methodology and decompose excess return shocks for foreign (nonUS) stocks into four components: expected return shocks; cash-flow shocks; real interest-rate shocks; and real exchange rate shocks. 
The approximate present-value relation for a foreign stock excess return:

$f_{t+1}-E_{t} f_{t+1}=\left(E_{t+1}-E_{t}\right)\left(\sum_{j=0}^{\infty} \rho_{e}^{j} \Delta d_{t+1+j}-\sum_{j=0}^{\infty} \rho_{e}^{j} r_{t+1+j}-\sum_{j=0}^{\infty} \rho_{e}^{j} \Delta q_{t+1+j}-\sum_{j=1}^{\infty} \rho_{e}^{j} f_{t+1+j}\right)$

where $f$ is the log foreign equity return in excess of the risk-free rate, $r$ is the real interest rate, $d$ is the $\log$ real dividend paid, $q$ is the log real exchange rate, and $\rho_{e}$ is a constant of linearization that is slightly less than one. ${ }^{5}$ We can write Equation (1) more succinctly to express the unexpected excess equity return $\tilde{f}$ as:

$$
\tilde{f}=\tilde{f}_{d}-\tilde{f}_{r}-\tilde{f}_{q}-\tilde{f}_{f}
$$

where $\tilde{f}_{d}$ is the cash-flow news, $\tilde{f}_{r}$ is the interest-rate news, $\tilde{f}_{q}$ is the exchange rate news, and $\tilde{f}_{f}$ is the expected excess returns news.

Equation (2) is a dynamic accounting identity that imposes internal consistency on expectations: it is not a behavioural model. It says that, other things being equal, an upward revision in forecast future dividends will have a positive impact on today's stock return. On the contrary, an increase in expected future excess returns that is not accompanied by revisions in forecast dividends, interest rates and exchange rates will lead to a fall in today's stock price so that higher future returns can be generated from the same cash flow. Similarly, positive news about future interest rates is negatively related to today's stock prices.

\subsection{International Bond Return Decomposition}

An equation analogous to (2) can be derived for the bond market. For international long-term coupon bonds, shocks to the foreign one-period log bond excess return $x$ can be decomposed

\footnotetext{
${ }^{5}$ More specifically, the constant $\rho_{e}$ is calculated as $\rho_{e}=\frac{1}{1+\exp (\overline{d p})}$, where $\overline{d p}$ is the sample mean of the $\log$ dividend-price ratio; in our sample, $\rho_{e}$ averages 0.9972 across countries.
} 
approximately as:

$$
x_{t+1}-E_{t} x_{t+1}=\left(E_{t+1}-E_{t}\right) \sum_{j=1}^{\infty} \rho_{b}^{j}\left(-\pi_{t+1+j}-r_{t+1+j}-\Delta q_{t+1+j}-x_{t+1+j}\right),
$$

where $\pi$ is the log one-period inflation rate, and $\rho_{b}$ is a constant of linearization that is slightly less than one. ${ }^{6}$ We can write Equation (3) more succinctly to express the unexpected excess bond return $\tilde{x}$ as:

$$
\tilde{x}=-\tilde{x}_{\pi}-\tilde{x}_{r}-\tilde{x}_{q}-\tilde{x}_{x}
$$

where $\tilde{x}_{\pi}$ is the inflation news, $\tilde{x}_{r}$ is the interest-rate news, $\tilde{x}_{q}$ is the exchange rate news, and $\tilde{x}_{x}$ is the bond expected excess returns news.

This decomposition says that positive unexpected excess bond returns are associated to either a negative change in expected inflation rates, or a decrease in expected future real interest rates or excess bond returns, or real exchange rates. Changes in expected inflation rates alter the expected real value of the fixed nominal payoff of the bond; even if the expected real bond returns are constant, a variation of expected inflation rates can generate capital gains or losses.

Campbell and Ammer (1993) derive a similar decomposition for unexpected excess returns on domestic $n$-period zero-coupon bonds. Unlike ours, their decomposition is exact, does not involve discounting, and sums up to $n-1$ instead of $\infty$. But given that our dataset consists of yields on international long-term coupon bonds, a different decomposition applies to our case. Engsted and Tanggaard (2001) build on Shiller and Beltratti (1992) to derive the decomposition for a domestic long-term coupon bond. The decomposition in Equation (3) extends that of Engsted and Tanggaard (2001) for international local-currency long-term coupon bonds.

\footnotetext{
${ }^{6}$ More specifically, the constant $\rho_{b}$ is calculated as $\rho_{b}=\exp (-\bar{Y})$, where $\bar{Y}$ is the mean consol yield; in our sample, $\rho_{b}$ averages 0.9961 across countries.
} 


\subsection{VAR Specification}

We can estimate the components of the decompositions in equations (1) and (3) by resorting to a vector autoregression (VAR) model. We derive expectations using forecasts from the VAR:

$$
z_{t}=\sum_{j=1}^{p} A_{j} z_{t-j}+u_{t}
$$

where $p$ is the number of lags that we include in our VAR. ${ }^{7}$ The vector $z$ includes the following state variables:

$$
z=\left[f, \text { flows }_{e}, x, \text { flows }_{b}, r, \Delta q, \Delta i, d p, \Delta d, f_{U S}, x_{U S}, d p_{U S},\right]^{\prime},
$$

where $f$ and $x$ are respectively the log excess returns of the foreign equity market and the foreign bond market; $r$ is the US real interest rate, $\Delta i$ is the change in the nominal US T-bill rate, $d p$ is the foreign dividend-price ratio, $\Delta d$ is the $\log$ dividend growth, and $\Delta q$ is the change in the log real exchange rate. These variables are among those most commonly suggested in the return predictability literature (see, e.g., Welch and Goyal, 2008; Rapach and Zhou, 2013). The inclusion of the dividend-price ratio is particularly important, not only because it is a potentially good forecaster of equity returns, but also because the equity return decomposition holds only conditional on an information set that includes prices (Campbell and Ammer, 1993; Engsted, Pedersen, and Tanggaard, 2012b). We include the US return and dividend-price ratios $\left(f_{U S}\right.$ and $\left.d p_{U S}\right)$ because they turn out to improve the return forecasts in our sample; this is in line with Rapach, Strauss, and Zhou (2013), who find that lagged US returns significantly predict returns in many non-US countries. Finally, we also include information about portfolio flows into the equity and bond markets (flows $e_{e}$ and flows ), measured as the ratio of their dollar value to the relevant country's nominal GDP, because

\footnotetext{
${ }^{7}$ We select the optimal number of lags using the Akaike Information Criterion; this optimal number of lags turns out to be equal to one in our sample.
} 
we want to study the interaction between returns and international investment flows. ${ }^{8}$

Innovations in equity excess returns and their components can now be obtained directly from the VAR. For instance, given that:

$$
\left(E_{t}-E_{t-1}\right) z_{t+j}=A^{j} u_{t}
$$

innovations to equity excess returns $\tilde{f}$ can be obtained directly as $\tilde{f}=e 1^{\prime} u_{t}$, where $e 1=$ $(1,0, \ldots, 0)^{\prime}$ is a selection vector that picks out the innovation in equity excess returns. By the perpetuity formula, infinite-horizon cumulative innovations can be derived as $\left(E_{t}-\right.$ $\left.E_{t-1}\right) \sum_{j=1}^{\infty} z_{t+j}=A(I-A)^{-1} u_{t}$. By the same token, we have that $\left(E_{t}-E_{t-1}\right) \sum_{j=1}^{\infty} z_{t+k+j}=$ $A^{k+1}(I-A)^{-1} u_{t}$, so that the innovation in cumulative expected excess returns $k$ periods forward, $\left(E_{t}-E_{t-1}\right) \sum_{j=1}^{\infty}\left(\rho_{e}^{j} f_{t+j}-\rho_{e}^{j+k} f_{t+k+j}\right)$, can be derived as:

$$
\tilde{f}_{f, t+k}=e 1^{\prime} \Phi(k) u_{t}
$$

where $\Phi(k)$ is the cumulative innovation matrix $k$ periods forward:

$$
\Phi(k)=\left(\Gamma-\Gamma^{k+1}\right)(I-\Gamma)^{-1},
$$

with $\Gamma=\rho_{e} A$. We can retrieve the real rate component and the exchange rate component of the equity return decomposition in Equation (2) in an analogous fashion.

For innovations beginning at time $t$, the infinite-horizon cumulative matrix is $\Phi \equiv$ $\Phi(\infty)=\Gamma(I-\Gamma)^{-1}$. The total impulse response function for the $i$-th shock $e i^{\prime} \Psi u_{t}$ is defined as the sum of the infinite-horizon cumulative expected innovations and the shock it-

\footnotetext{
${ }^{8}$ A potential additional predictor for bond returns could be the Cochrane and Piazzesi (2005) factor based on forward rates. However, there are not enough data available to build this factor for our sample of 31 countries, which include both developed and emerging markets. Also, it is not obvious exactly which data (more specifically, which forward rates) to use to construct this factor in our framework, and particularly for them to be consistent with the dependent variable, i.e. bond returns. Our bond returns are derived from JP Morgan benchmark indices, which track the performance of a varied basket of fixed rate issuances, weighted by market capitalisation and whose inclusion in the index is subject to tradability, liquidity, credit rating and valuation criteria. This information is not publicly available.
} 
self: $e i^{\prime} \Psi u_{t}=e i^{\prime}(I+\Phi(\infty)) u_{t}$. For innovations beginning at time $t+k$, the infinite-horizon cumulative matrix is $\Phi-\Phi(k)$; when we include the shock itself, the infinite-horizon cumulative matrix is $\Psi-\Psi(k)$. In the presentation of the results in Section 4, we refer to the cumulative innovations beginning at time $t$ and up to the first quarter ( $k=3$ using monthly data) as the "short-run" innovations. We refer to the infinite-horizon cumulative innovations beginning after the first quarter as the "long-run" innovations.

Finally, we can back out the expected cash-flow component $\tilde{f}_{d}$ by rearranging Equation (2) to obtain:

$$
\tilde{f}_{d}=\tilde{f}+\tilde{f}_{r}+\tilde{f}_{q}+\tilde{f}_{f}
$$

We estimate each of the components of the bonds excess returns in an analogous fashion. First we compute $\tilde{x}, \tilde{x}_{r}, \tilde{x}_{q}$ and $\tilde{x}_{x}$ from the residuals of the VAR. Then we estimate $\tilde{x}_{\pi}$ by rearranging equation (4). Chen and Zhao (2009) claim that this methodology is sensitive to the decision to estimate expected return news directly and treat news about real cash payments as a residual. However, Campbell, Polk, and Vuolteenaho (2010) and Engsted et al. (2012b) show that this claim is incorrect. In a first-order VAR that includes the dividend price ratio and additional state variables that capture part of the predictability of returns and dividend growth not captured in the dividend price ratio, it does not matter which news component is treated as a residual and which ones are estimated directly (Campbell et al., 2010; Engsted et al., 2012b). ${ }^{9}$ Of course, the estimation of the news components will depend on the selection of the state variables in the VAR model; this is naturally expected because the state variables will always be a subset of the full information set available to investors, and therefore may not capture the full time variation of the return components. The point here is that the relative importance of the news components will not depend on which of the components is treated as a residual. When we estimate the cash-flow news directly, our

\footnotetext{
${ }^{9}$ The only factor that could make the results differ is the approximation error in the underlying log-linear return approximation. This approximation error is generally found to be empirically small; see, e.g., Engsted, Pedersen, and Tanggaard (2012a).
} 
results indeed hold, confirming empirically the claims of Campbell et al. (2010) and Engsted et al. (2012b).

It is worth noting that we do not impose the same coefficients across all countries. We estimate the VAR coefficients using the mean group estimator, i.e. by running separate timeseries regressions for each country and then averaging the coefficients over countries. Pesaran and Smith (1995) show that the mean group estimator leads to consistent estimates of the average coefficients in dynamic panel models like our VAR.

Standard errors of all the relevant statistics are calculated using the delete-1 jackknife method of Shao and Rao (1993). The jackknife is a non-parametric estimator that generates standard errors that are consistent even under cross-sectional dependence. The procedure starts by calculating an estimator $\theta$ from the entire sample of size T. Then, T new samples of size $T-1$ are recorded, omitting one cross section at a time. Next, one calculates the estimator $\theta_{[i]}$ from each one of the new $i$-th samples. Then, pseudo-values are calculated as T times $\theta$ less $T-1$ times the $\theta_{[i]}$. Finally, the variance of pseudo-values is the estimated variance of the regression coefficient estimator. Vuolteenaho (2002) and Froot and Ramadorai (2005) apply the delete-1 jackknife to a panel VAR, similarly to our paper.

\section{$3 \quad$ Data and Descriptive Statistics}

Our dataset covers a total of 31 countries, which we divide in two subgroups. The first subgroup is what we call the Advanced Economies group, which includes 18 countries: Austria; Belgium; Canada; Switzerland; Germany; Denmark; Spain; Finland; France; Greece; Ireland; Italy; Japan; Norway; New Zealand; Sweden; the United Kingdom; and the United States. The second subgroup is what we call the Emerging Markets group (13 countries), and which consists of Czech Republic; Hong Kong; Hungary; Indonesia; India; Mexico; Malaysia; Philippines; Russia; Singapore; South Korea; Thailand; and South Africa.

For each of these countries we measure monthly equity market returns using MSCI equity index data at daily frequency obtained from Thomson Financial Datastream. We collect total 
return indices in US dollars. Yields on long-term coupon bonds are from Global Financial Data. Dividend yields data are also from the MSCI database. We proxy the risk-free rate with the one-month US T-bill rate, sourced from Kenneth French's website.

Monthly fund flows data are from EPFR, which tracks portfolio flows from both institutional and retail investors into financial products such as mutual funds, ETFs, and closed-end funds. Every month, EPFR collects data from each fund manager or administrator about the fund's total net assets, changes in net asset values, and country allocations. ${ }^{10}$ From these data, flows (net of redemptions) into funds are calculated. Flows into individual countries are then estimated as follows: the average allocation to a given country from a fund group is multiplied by the total flows into that fund group; then, the same calculation is done across all fund groups, and these figures are added up to get the estimated total flows to that country. For example, flows to Brazilian equities are calculated as the sum of: (i) flows to Brazil-dedicated equity funds; (ii) the share of flows to Latin America-dedicated equity funds allocated to Brazil; (iii) the share of flows to so-called "Global Emerging Market" equity funds allocated to Brazil; and (iv) the share of flows to global equity funds allocated to Brazil. These flows are correlated with the balance-of-payments gross portfolio inflows to a country as shown in Fratzscher (2011). We normalise flow data by their country's nominal GDP.

Table 1 displays descriptive statistics of these data. Monthly equity flows average about $4 \%$ of GDP across countries, whereas monthly bond flows average about $2 \%$ of GDP. Standard deviations are on average about $6 \%$ for equities and $3 \%$ for bonds. Flows tend to be strongly positively autocorrelated, with average first-order autocorrelations of about 0.4 for equities and 0.6 for bonds.

Exchange rates are calculated computing the difference between log equity returns in US

\footnotetext{
${ }^{10} \mathrm{EPFR}$ also collects fund flows at a weekly frequency. However, in our analysis we prefer to use the data at the monthly frequency for three reasons: (i) country allocations are only available at the monthly frequency; (ii) funds that report at the weekly frequency are only a subset of those reporting monthly, so that the latter group covers a much larger number of funds and can give a more comprehensive view of funds' behaviour; and (iii) our dataset for bond yields, which we later match to the flow dataset, are only available at a monthly frequency for many countries.
} 
dollars and log equity returns in local currency. We calculate monthly inflation data as the percentage change in CPI from IMF IFS database. The resulting database contains time series running from January 2004 to December 2013 for the 31 countries.

\section{Results}

\subsection{Variance Decomposition of International Equity Returns}

We use the VAR specification presented in Section 2.3 to calculate the proximate components of unexpected equity excess returns in Equation (2). The variance of excess returns can be decomposed as follows according to Equation (2):

$$
\begin{array}{r}
\operatorname{var}(\tilde{f})=\operatorname{var}\left(\tilde{f}_{d}\right)+\operatorname{var}\left(\tilde{f}_{r}\right)+\operatorname{var}\left(\tilde{f}_{q}\right)+\operatorname{var}\left(\tilde{f}_{f}\right) \\
-2 \operatorname{cov}\left(\tilde{f}_{d}, \tilde{f}_{r}\right)-2 \operatorname{cov}\left(\tilde{f}_{d}, \tilde{f}_{q}\right)-2 \operatorname{cov}\left(\tilde{f}_{d}, \tilde{f}_{f}\right) \\
+2 \operatorname{cov}\left(\tilde{f}_{r}, \tilde{f}_{q}\right)+2 \operatorname{cov}\left(\tilde{f}_{r}, \tilde{f}_{f}\right)+2 \operatorname{cov}\left(\tilde{f}_{q}, \tilde{f}_{f}\right) .
\end{array}
$$

Panel A of Table 2 displays the contribution of each of the terms in Equation (8) to the overall variance of the unexpected equity excess return. We scale each component by the variance of the unexpected excess return $\operatorname{var}(\tilde{f})$ so that they sum to one. Results are presented for the entire sample of countries and also for the sub-sample of advanced and emerging countries separately.

News about future dividends is the main sources of variation of unexpected equity returns. More specifically, the variance of dividend news is the largest component of the variance of equity returns for both advanced and emerging economies. This findings is at odds with the evidence commonly found in the literature, reported for the Unites States, that asset price movements are mainly due to innovations in expected returns, or equivalently to discount rate variation (e.g., Cochrane, 2008, 2011). Cochrane (2008) reaches this conclusion as he finds absence of dividend growth predictability (equivalently, absence of variation in cash- 
flow expectations) for the aggregate US equity market via means of OLS regressions of the dividend growth on the dividend yield; this evidence implies that returns are predictable (equivalently, that discount rates are time-varying) to account for the observed time variation of dividend yields. ${ }^{11}$ Results from our VAR, which pool information for many more countries, suggest the opposite. We find that dividend growth is predictable: the OLS coefficient on the dividend yield in the dividend growth equation is -0.05 and is statistically significant at the five per cent confidence level. ${ }^{12}$

A number of recent papers confirm our results about the relative size of the cash-flow and the excess return component. Plazzi (2010) finds that expected return shocks prevail over cash-flow shocks in the US, while the opposite is true in the UK. Vuolteenaho (2002) studies firm-level stock returns in the US and finds that the cash-flow component always prevails. Phylaktis and Ravazzolo (2002) concentrate on a sample of countries in the PacificBasin region and show that the cash-flow shock component prevails over the expected-return component. Finally, Rangvid et al. (2013) find that in a large number of non-US countries, dividend growth is predictable using dividend yields. They interpret this result as an evidence that news about future dividends is the main drivers of return innovations.

News about exchange rates changes contributes little, if anything, to the variance of unexpected equity returns. This finding is consistent with that of Ammer and Mei (1996) and Phylaktis and Ravazzolo (2002), who find that the exchange rate component does not contribute much to the variance of the UK and Asian equity markets. It is also in line with the results of the cross-sectional asset pricing exercise of Cenedese et al. (2015), who find

\footnotetext{
${ }^{11}$ Van Binsbergen and Koijen (2010), Plazzi et al. (2010), and Koijen and Nieuwerburgh (2011) argue that OLS regressions may miss substantial variation in expected cash flows and that structural $R^{2} \mathrm{~s}$ - that is, the underlying variation in conditional expectations of the data generating process - may differ significantly from the OLS $R^{2}$. They propose present-value models, estimated via GMM or maximum likelihood, to capture the time variation in expected cash-flow growth that is not captured by OLS regressions. While the application of these present-value models in an international setting is a promising area, we leave this for future research. Our pooled VAR, which combines information from many countries, appears to capture already at least some of the time variation in expected cash flows.

${ }^{12}$ We don't report the full matrix of coefficients for brevity and ease of exposition. Another interesting result emerging from the analysis of the VAR coefficients is that lagged equity portfolio flows also help predict dividend growth (coefficient 0.029, significant at the 10 per cent confidence level).
} 
that returns on international equity markets are broadly unrelated to exchange rates.

The relatively large standard errors in Table 2 suggest that the contribution of the components is only imprecisely estimated. Also, the several covariance terms in the decomposition make results difficult to interpret. Therefore, we complement results in Table 2 with those obtained with an alternative methodology to assess the contribution of the different return components to the time variation of unexpected excess returns. First, we orthogonalise each component using a Cholesky decomposition. Then, we measure the $\mathrm{R}^{2}$ values in regressions of unexpected excess returns on each of the orthogonalised components. ${ }^{13}$ Table 3 reports these $\mathrm{R}^{2}$ values. Estimates are now more precise, and are consistent with the results above: dividend shocks account for most of the time variation of unexpected excess returns in our sample.

\subsection{Variance Decomposition of International Bond Returns}

We use the VAR specification discussed in Section 2.3 to evaluate the contribution of each proximate component to the overall excess return in the bond markets. According to equation (4), the variance of excess returns can be decomposed as follows:

$$
\begin{array}{r}
\operatorname{var}(\tilde{x})=\operatorname{var}\left(\tilde{x}_{\pi}\right)+\operatorname{var}\left(\tilde{x}_{r}\right)+\operatorname{var}\left(\tilde{x}_{q}\right)+\operatorname{var}\left(\tilde{x}_{x}\right) \\
+2 \operatorname{cov}\left(\tilde{x}_{\pi}, \tilde{x}_{r}\right)+2 \operatorname{cov}\left(\tilde{x}_{\pi}, \tilde{x}_{q}\right)+2 \operatorname{cov}\left(\tilde{x}_{\pi}, \tilde{x}_{x}\right) \\
+2 \operatorname{cov}\left(\tilde{x}_{r}, \tilde{x}_{q}\right)+2 \operatorname{cov}\left(\tilde{x}_{r}, \tilde{x}_{x}\right)+2 \operatorname{cov}\left(\tilde{x}_{q}, \tilde{x}_{x}\right) .
\end{array}
$$

Panel B in Table 2 contains the variance decomposition for international bond returns. Each component is normalised by the variance of the unexpected excess bond return $\operatorname{var}(\tilde{x})$ so that they sum up to one.

News about future inflation and real interest rates account for most of the variation of

\footnotetext{
${ }^{13}$ Following Engsted and Tanggaard (2001), the components are ordered as follows: dividend shocks $\tilde{f}_{d}$, real rate shocks $\tilde{f}_{r}$, exchange rate shocks $\tilde{f}_{q}$, and expected return shocks $\tilde{f}_{f}$. Our results are qualitatively robust to different orderings of the variables; ordering expected return shocks before dividend shocks actually reinforces the result, as dividend shocks now account for about 98 per cent of time variation of unexpected returns.
} 
unexpected bond returns. The importance of inflation news in explaining the variance of unexpected bond returns is in line with the results of Campbell and Ammer (1993) for the US bonds market and the results of Engsted and Tanggaard (2001) for the Danish bond market.

Estimates for bond returns are also imprecisely estimated as shown by their relatively large standard errors. To address this problem our results are complemented with an alternative methodology that measures the $\mathrm{R}^{2}$ values in regressions of unexpected excess returns on each of the orthogonalised components. ${ }^{14}$ Table 3 reports these $\mathrm{R}^{2}$ values. Estimates are more precise, and are consistent with the results above: inflation shocks account for most of the time variation of unexpected bond returns in our sample.

\subsection{Relation between asset return components and portfolio flows}

\section{International equity markets}

We use the return decomposition contained in equation (2) to study the relation between news about portfolio flows and the proximate causes of excess returns. Table 4 summarises covariances between return components and portfolio flows for international equity markets. The table is divided into three panels. Panel A reports results for the entire sample of countries. Panel B reports results for advanced economies, while Panel C displays results for emerging market economies. Each cell contains estimates of the scaled covariances between the elements indicated in the row and column headings. ${ }^{15}$ Covariances are normalised using the product of the standard deviation of unexpected excess returns and the standard deviation of unexpected flows to facilitate comparison across the elements of the table.

\footnotetext{
${ }^{14}$ Following Engsted and Tanggaard (2001), the components are ordered as follows: inflation shocks $\tilde{x}_{\pi}$, real rate shocks $\tilde{x}_{r}$, exchange rate shocks $\tilde{x}_{q}$, and expected return shocks $\tilde{x}_{x}$. Our results are qualitatively robust to different orderings of the variables; ordering expected return shocks before inflation news changes the results somewhat significantly in quantitative terms, as inflation shocks now account for about 58 per cent of time variation of unexpected returns as opposed to 42 per cent in the case of expected return shocks.

${ }^{15}$ The decomposition of flows maps directly into the definition of the cumulated impulse response function. Unexpected flows a can be retrieved from the error term of the VAR. Total flows correspond to the infinitehorizon cumulated impulse response function. Short-run and long-run expected flows are obtained breaking down the infinite-horizon cumulated impulse response function in two parts.
} 
The first column in each of the panels contains normalised covariances between excess returns news and news about portfolio flows at different horizons. The contemporaneous covariance between flow and return news in cell $(1,1)$ is positive and significant. This covariance term can be interpreted as an estimate of price impact. On impact, shocks to excess returns are positively associated with shocks to flows. Results are consistent across the three panels. The second and the third rows of column 1 explore flows reaction to an excess return shock in the short and in the long run. In the short run-cell $(2,1)$ - flows react positively. This is consistent with investors chasing returns and increasing their exposure to stock markets that have experienced unexpectedly high returns. However, the trendchasing behaviour is short lived. After one quarter, the covariance between expected flows and returns turns negative as reported in cell $(3,1)$. The change of the covariance sign is consistent with investors initially overreacting to excess return shocks and reversing some of their positions afterwards. This finding is especially strong for emerging economies. Finally, the last row of Table 4 contains the covariance between the infinite-horizon cumulative flow innovation and the excess return shock. The positive and significant covariance reported in cell $(4,1)$ suggests that the observed short-term positive correlation is not entirely offset by the long-term negative correlation.

Results in Table 4 are confirmed by the cumulated impulse response functions of the VAR. Figure 1 contains the cumulated impulse response function of equity flows following an excess return shock. ${ }^{16}$ On impact international equity flows react positively to a return shock. Equity inflows remain positive for the first five months after the shock and slowly revert afterwards. The humped shape of the impulse response function confirms the initial overreaction which is corrected about one quarter after the initial shock.

We also investigate the existence of an anticipation effect. This is the comovement of

\footnotetext{
${ }^{16}$ The shock is induced by setting the equity return shock in the VAR error vector equal to one standard deviations while the other elements of the VAR error vector are set equal to their conditional expectations, conditioning on the excess return component being equal to one standard deviation. For a similar approach in setting the impulse responses, see Vuolteenaho (2002), Cohen, Gompers, and Vuolteenaho (2002), and Froot and Ramadorai (2005).
} 
expected future returns and portfolio flows (first row of Table 4). Cell $(1,2)$ shows that unexpected positive flow shocks are associated with an upward revision in cumulated expected future returns. Investors anticipate future returns and invest in countries that display higher expected returns. Again evidence is found that the positive relation between flows and returns breaks down in the long run and the covariance between the two becomes negative as reported in cell $(1,3)$. Figure 2 shows the cumulated impulse response function for excess returns following a portfolio flow shock. Following an unexpected flow shock equity returns tend to increase in the short run. However, after about five months equity returns begin to decline.

The fourth and the fifth columns of Table 4 display the covariances between portfolio flows and the real rate and the exchange rate component respectively. The contribution of these two components is modest and covariance terms are statistically insignificant. The last column displays the relation between portfolio flows and dividend news. Uncovering the relation between flows and the dividend component of returns is crucial as news about future dividends accounts for most of the variance in international equity returns. Dividend shocks are found to be followed by capital inflows on the impact and up to a quarter after the shock. This is especially true for emerging markets. In the long run the relation disappears and the covariance term turns negative and insignificant. The infinite horizon cumulated effect of a dividend shock - cell $(4,6)$ - is positive and significant. Figure 3 displays the cumulative impulse response function of equity flows to a dividend shock. ${ }^{17}$ Following the initial positive reaction, the covariance between flows and cash-flow news weakens as it is testified by the flattening of the impulse response function. While the dynamics appear to be similar in each of the three samples, the significance level is higher for emerging economies than for advanced economies.

The analysis conducted so far suggests that investors chase returns at least in the short

\footnotetext{
${ }^{17}$ The shock is induced setting the VAR error vector to a constrained maximum likelihood value, imposing the constraint that cash-flow shock equals one standard deviations and that the expected return shock is zero. For a similar approach in setting the impulse responses see Vuolteenaho (2002).
} 
run. The covariance terms in columns one and six of Table 4 suggest that investors increase their equity holdings following a positive excess return shock especially when this is induced by a revision in cash-flow expectations. However, according to equation (2), a positive excess return shock may also be triggered by a negative shock to expected returns. ${ }^{18}$ In this case the resulting appreciation of return is only temporary, as the price must eventually fall so that future returns will be lower. ${ }^{19}$ Figure 4 displays the cumulated impulse response function for equity flows following a negative shock to expected returns. ${ }^{20}$ Countries experience equity outflows even in the presence of returns' appreciation. This implies that investors are able to discriminate between appreciations that are caused by an upward revision of expected future dividend growth and excess returns that are caused by a downward revision of expected future returns. In other words, international investors are not mechanical momentum traders and they respond to a short-term transitory appreciation by selling and to a permanent appreciation by buying.

The finding that flows react differently to different types of shocks is intriguing and suggests that investors behave rationally when taking investment decisions. A natural question is whether institutional investors behave differently from retail investors, as one might expect that the former group, mainly composed by professional portfolio managers, may react more rationally to shocks. We decompose fund flows into those coming from institutional and retail investors and run the same analysis above for these two different subsets. Figures 5 and 6 display the impulse response functions of institutional and retail equity flows, respectively, to a negative shock to expected equity excess returns. Institutional and retail investors react differently to this temporary equity appreciation: institutional flows are negative following

\footnotetext{
${ }^{18}$ Holding the other components constant, a fall in expected future returns may be achieved only through an increase in today's returns. We abstract from exchange rate and real rate shocks in this part of the analysis because we find that they are not important drivers of equity flows when looking the impulse response function.

${ }^{19}$ Campbell (1991) return decomposition is related to the Beveridge-Nelson decomposition in the timeseries literature, with the dividend shock corresponding to the nonstationary, permanent component and the expected return shock corresponding to the stationary, temporary component. See, e.g., Cohen et al. (2002).

${ }^{20}$ The shock is induced setting the VAR error vector to a constrained maximum likelihood value, imposing the constraint that the expected return shock equals one standard deviation and that all the other shocks are zero.
} 
such a shock, while retail flows are not statistically significant. This difference is consistent with institutional investors behaving more rationally than retail investors.

\section{International bond markets}

Table 5 summarises the relation between flows and returns in international bond markets in the same format as in Table 4. The first column reports the scaled covariance between unexpected bond excess returns and news about portfolio flows. Cell $(1,1)$ displays the contemporaneous covariance between bond flows and bond returns and measures the price effect. The estimated price impact is positive but the result is only significant for the sample of emerging economies.

Cell $(2,1)$ contains the covariance between the short-term expected flow news and unexpected excess returns. The covariance between flows and returns is positive and significant (with the exception of the developed economy sample) in the short run, while in the long run - cell $(3,1)$ - it becomes insignificant. The impulse response function in Figure 7 confirms the positive short-term impact of an excess return shock on portfolio bond flows. As the time passes, the impulse response flattens confirming the transitory nature of the relation between excess return shock and flow changes.

We also assess the existence and the magnitude of an anticipation analysing comovements between flow shocks and expected future returns. Expected returns react weakly to unexpected flow shocks in the short run as shown in cell $(1,2)$. In the long run instead-cell $(1,3)$ - a negative relation between flows and returns emerges. Results are more significant for the sample of emerging economies. The impulse response in Figure 8 describes the unexpected excess return reaction to a flow shocks. Positive flow shocks predict negative excess returns in the medium and in the long run.

The risk-free rate component explains some of the covariance between flows and returns especially for emerging economies. An upward revision in expectations about the US riskfree rate causes bond outflow on the impact - cell $(1,4)$ - and in the short run - cell $(2,4)$. 
The negative covariance between bond flows and the risk free rate is (weakly) significant for emerging economies while it is not for advanced economies. This result is consistent with the view that debt flows to emerging markets are correlated with monetary policy interventions and the business cycle of developed economies as suggested for instance by Ahmed and Zlate (2013). ${ }^{21}$ Finally, both inflation shocks and exchange rate shocks explain have little explanatory power for the comovements between flows and returns. Covariances are low and not significant for either component.

Figure 9 depicts the impulse response function describing flows reaction to an downward revision of expected bond returns. While in the equity market negative expected return shocks generate outflows, in the bond market we do not find the same result. The reaction of flows to expected future returns shocks is not significant. In unreported results, we find that the same statistically insignificant results hold when we analyse institutional and retail investors separately.

\section{Conclusions}

In this paper we study the relation between international mutual fund flows and the different return components of aggregate equity and bond markets. We decompose international equity and bond market returns into changes in expectations of future real cash payments, interest rates, exchange rates, and discount rates. We find that news about future dividend growth is the main source of variation for equity excess returns. Importantly, our findings

\footnotetext{
${ }^{21}$ In May 2013, chairman Ben Bernanke announced that the Federal Reserve would start "tapering" (or slowing down) its programme asset purchases; large outflows from emerging-market-dedicated mutual funds followed suit (this episode has been named "taper tantrum" by the financial press). This episode suggests a sharp sensitivity of international capital flows to revisions of expectations about the US risk-free rate. While a formal analysis of the relation between international capital flows and US monetary policy goes beyond the scope of this paper, we computed the 12-month rolling correlation between risk-free rate shocks and emerging-market bond flows and analyzed its evolution over time. We found two main results. First, the comovement between emerging-market bond flows and interest rate shocks is strong and negative. Secondly, this comovement became stronger during the global financial crisis. During the "taper tantrum" episode in May 2013 the correlation between international bond flows and interest rate shocks was stronger than ever before in our sample. This finding suggests that changes in the expectations about risk-free rates may play a key role in explaining the large movements in the international bonds market observed around May 2013.
} 
are at odds with the evidence commonly found in the literature, reported mostly for the US equity market, that asset price movements are mainly due to innovations in expected returns, or equivalently to discount rate variation. International bond returns instead are mainly driven by inflation news. News about exchange rates contributes little to the variance of unexpected equity and bond returns. When we analyse the relation between the proximate causes of excess returns and flows, we find evidence consistent with price pressure, shortterm trend chasing, and short-run overreaction in equity markets. Finally we find that international bond flows to emerging markets are more sensitive to revisions in expectations about future interest rates relative to equity flows. 


\section{$6 \quad$ Tables and Figures}

Figure 1. Impulse Response Function of Portfolio Equity Flows to an Excess Return Shock.

This figure shows the cumulated response of equity flows to a one standard deviation shock to excess returns. The response is shown at different return horizons (horizontal axis, scale in weeks). The solid line is the response of cumulated equity flows, while the dashed lines display \pm 2 -standarddeviation bounds estimated using the delete-1 jackknife method. Data pool emerging markets and developed economies together.

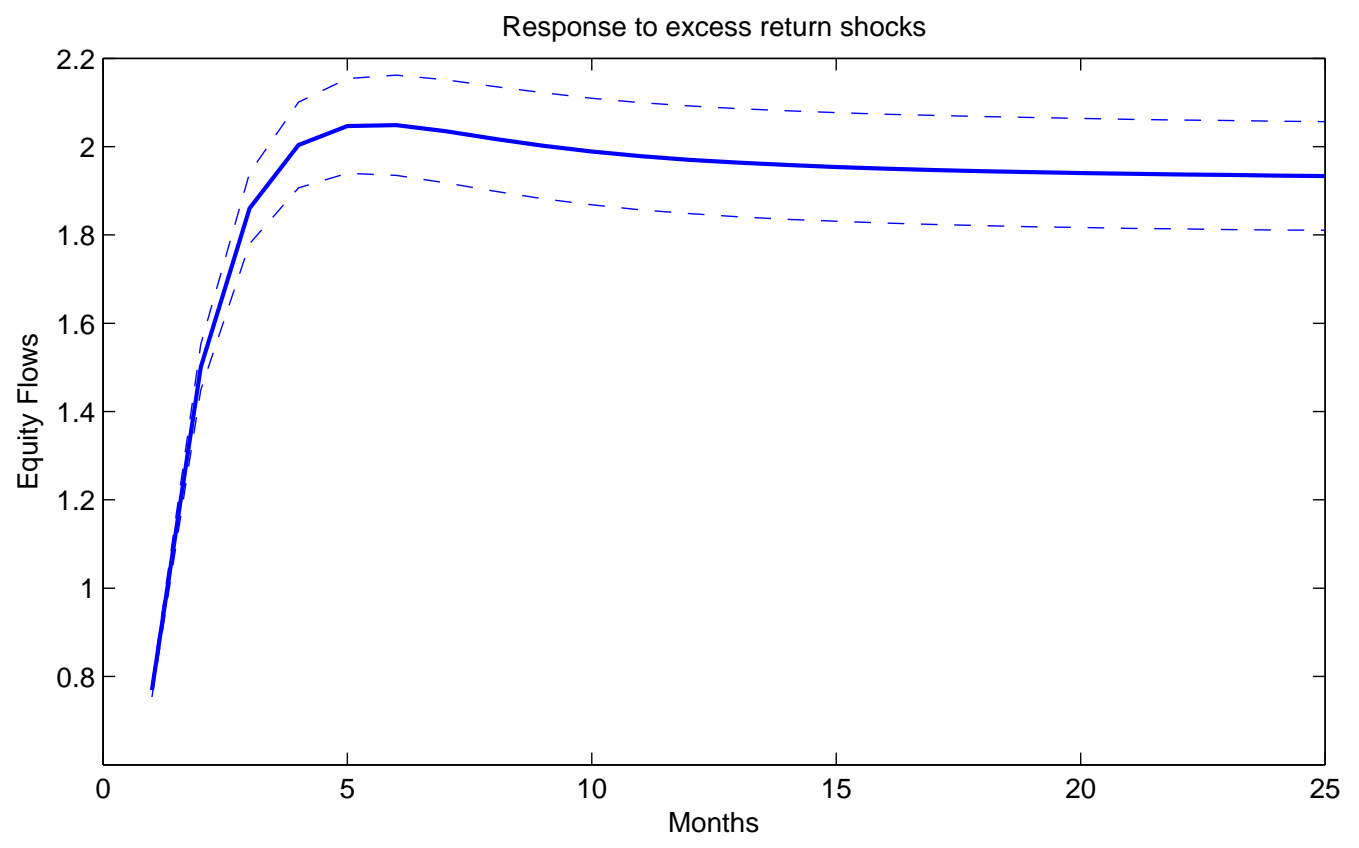


Figure 2. Impulse Response Function of Excess Return to an Equity Flow Shock.

This figure shows the cumulated response of equity excess returns to a one standard deviation shock to flows. The response is shown at different return horizons (horizontal axis, scale in weeks). The solid line is the response of cumulated equity excess returns, while the dashed lines display \pm 2 -standard-deviation bounds estimated using the delete-1 jackknife method. Data pool emerging markets and developed economies together.

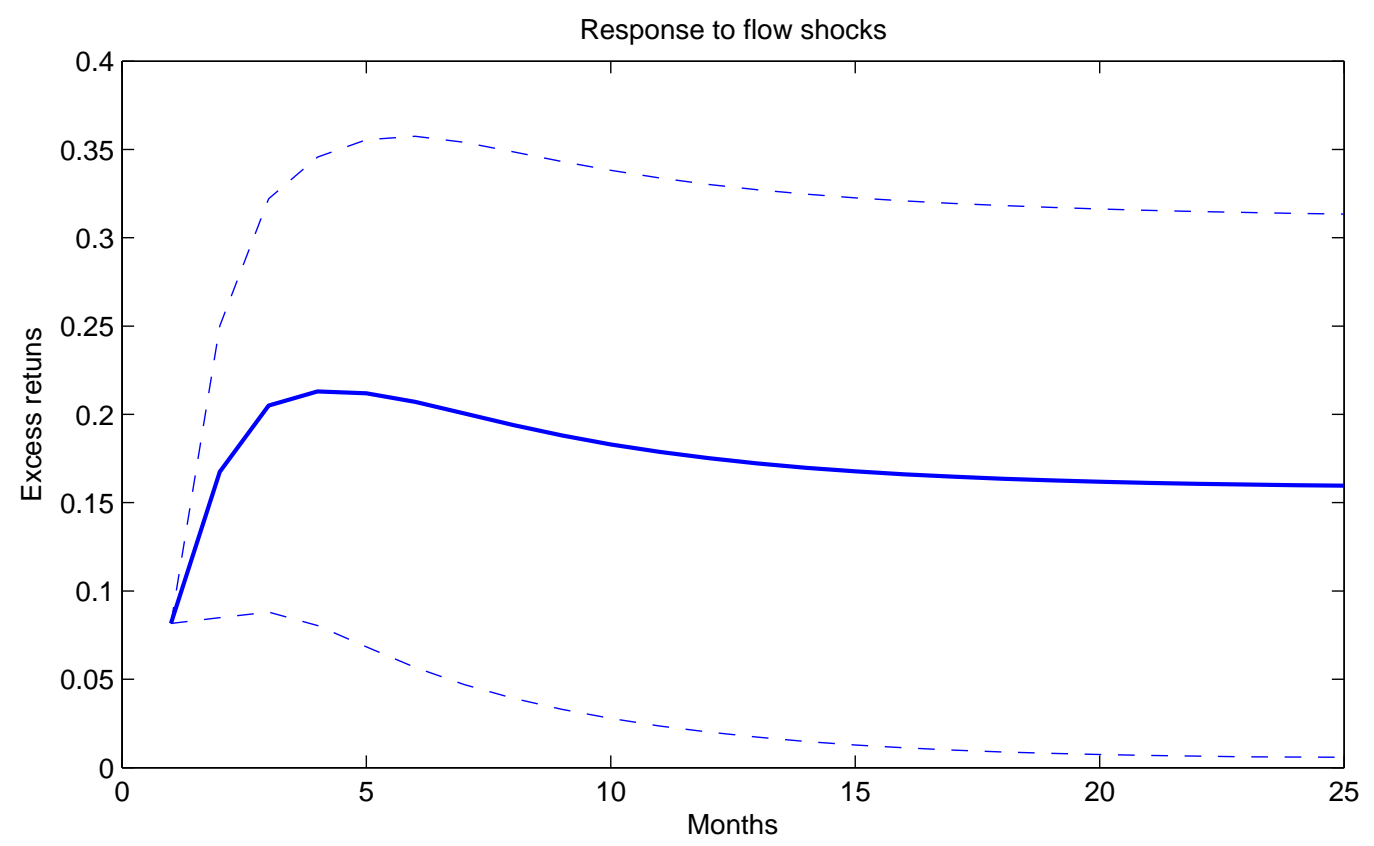


Figure 3. Impulse Response Function of Portfolio Equity Flows to a Cash-Flow Shock.

This figure shows the cumulated response of equity flows to a one standard deviation shock to cash-flow news. The shock is induced setting the VAR error vector to a constrained maximum likelihood value, imposing the constraint that cash-flow shock equals one standard deviations and that expected return news is zero. The response is shown at different return horizons (horizontal axis, scale in weeks). The solid line is the response of cumulated equity flows, while the dashed lines display \pm 2 -standard-deviation bounds estimated using the delete- 1 jackknife method. Data pool emerging markets and developed economies together

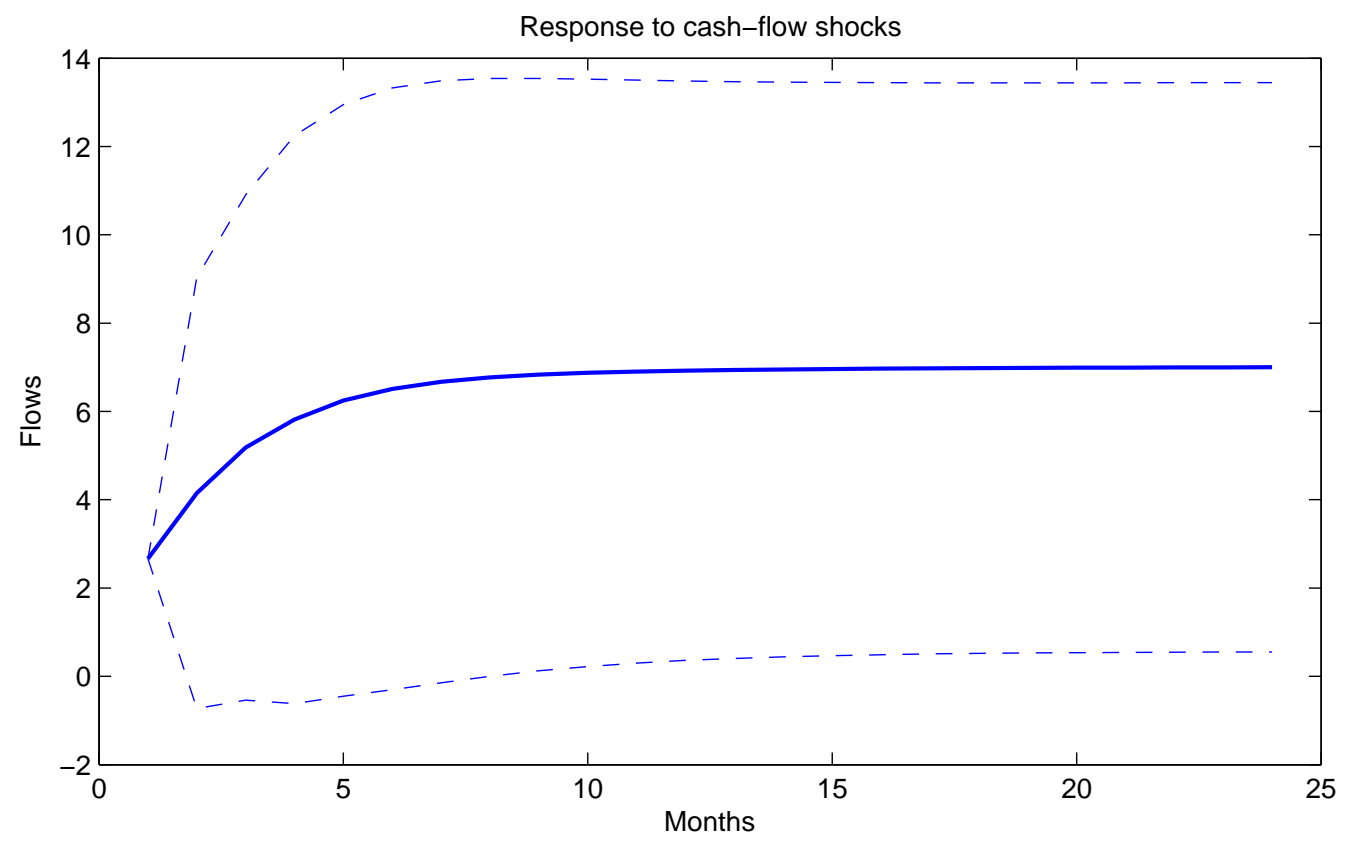


Figure 4. Impulse Response Function of Portfolio Equity Flows to a Negative Expected Return Shock.

This figure shows the cumulated response of equity flows to a one standard deviation negative expected returns shock. The shock is induced setting the VAR error vector to a constrained maximum likelihood value, imposing the constraint that excess return shock is equal to one standard deviations and that the expected cash-flow shock is zero. The response is shown at different return horizons (horizontal axis, scale in weeks). The solid line is the response of cumulated equity flows, while the dashed lines display \pm 2 -standard-deviation bounds estimated using the delete- 1 jackknife method. Data pool emerging markets and developed economies together

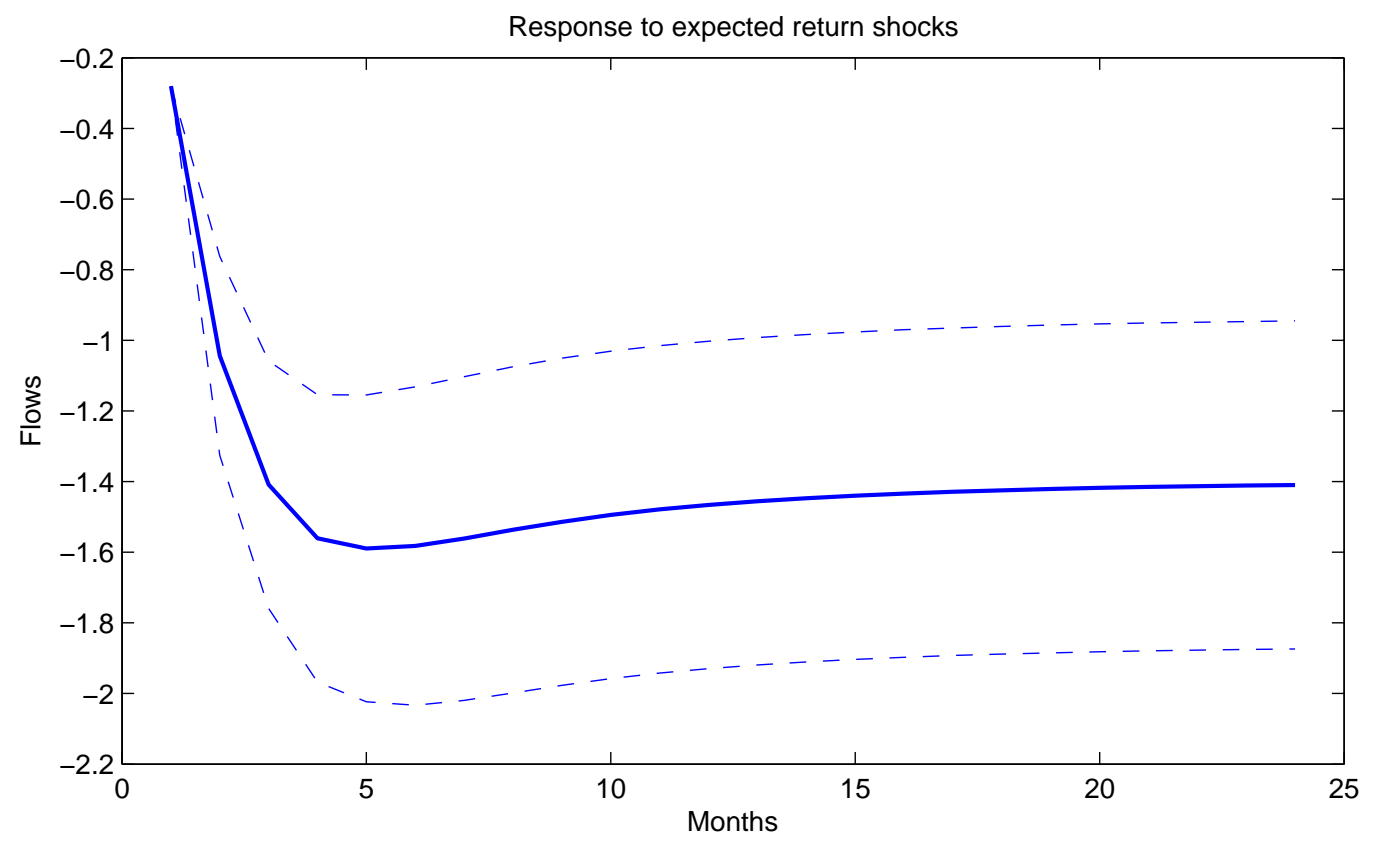


Figure 5. Impulse Response Function of Portfolio Equity Flows to a Negative Expected Return Shock: Institutional Investors

This figure shows the cumulated response of institutional investors equity flows to a one standard deviation negative expected returns shock. The shock is induced setting the VAR error vector to a constrained maximum likelihood value, imposing the constraint that excess return shock is equal to one standard deviations and that the expected cash-flow shock is zero. The response is shown at different return horizons (horizontal axis, scale in weeks). The solid line is the response of cumulated equity flows, while the dashed lines display \pm 2 -standard-deviation bounds estimated using the delete-1 jackknife method. Data pool emerging markets and developed economies together

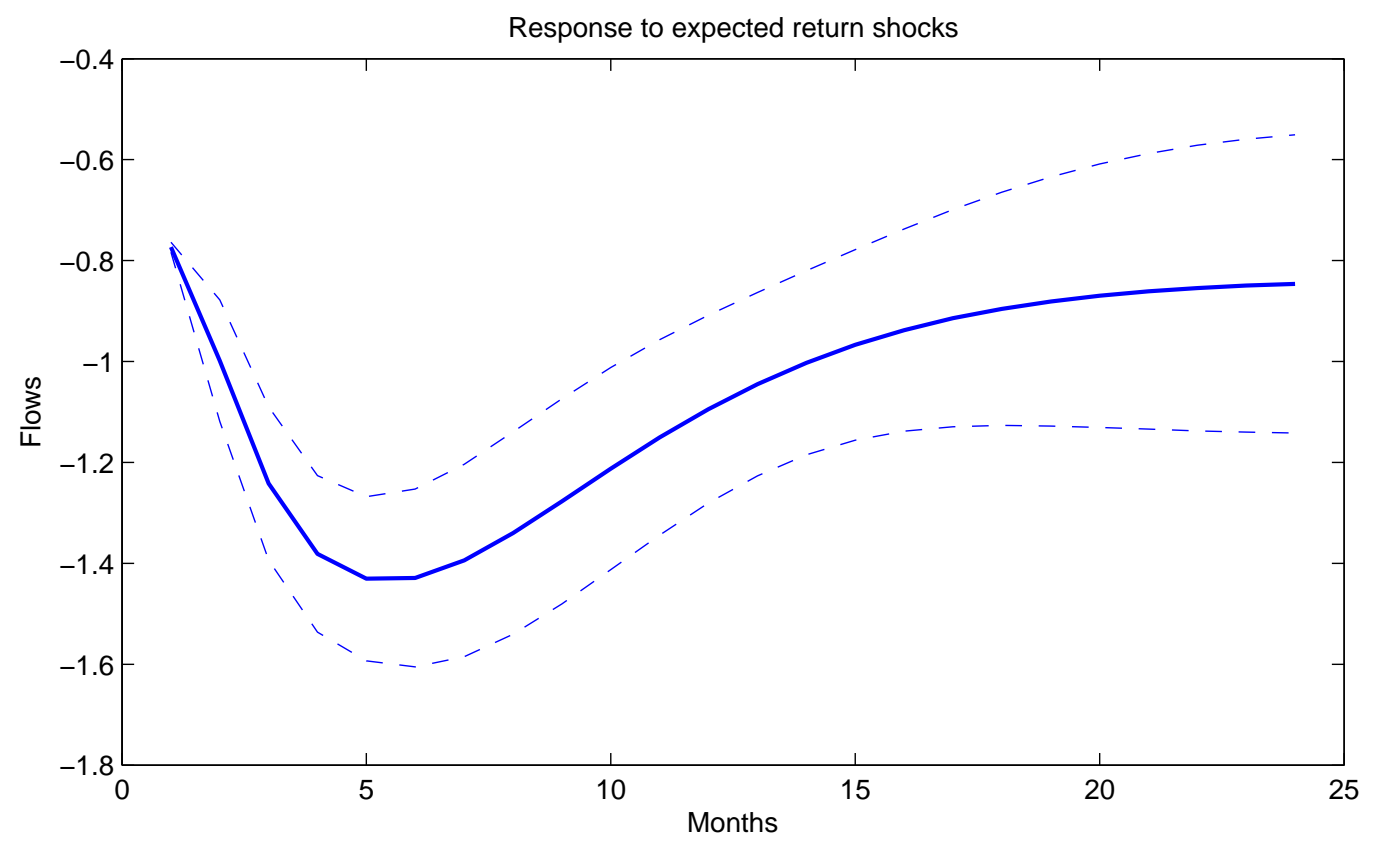


Figure 6. Impulse Response Function of Portfolio Equity Flows to a Negative Expected Return Shock: Retail Investors

This figure shows the cumulated response of retail investors equity flows to a one standard deviation negative expected returns shock. The shock is induced setting the VAR error vector to a constrained maximum likelihood value, imposing the constraint that excess return shock is equal to one standard deviations and that the expected cash-flow shock is zero. The response is shown at different return horizons (horizontal axis, scale in weeks). The solid line is the response of cumulated equity flows, while the dashed lines display \pm 2 -standard-deviation bounds estimated using the delete- 1 jackknife method. Data pool emerging markets and developed economies together

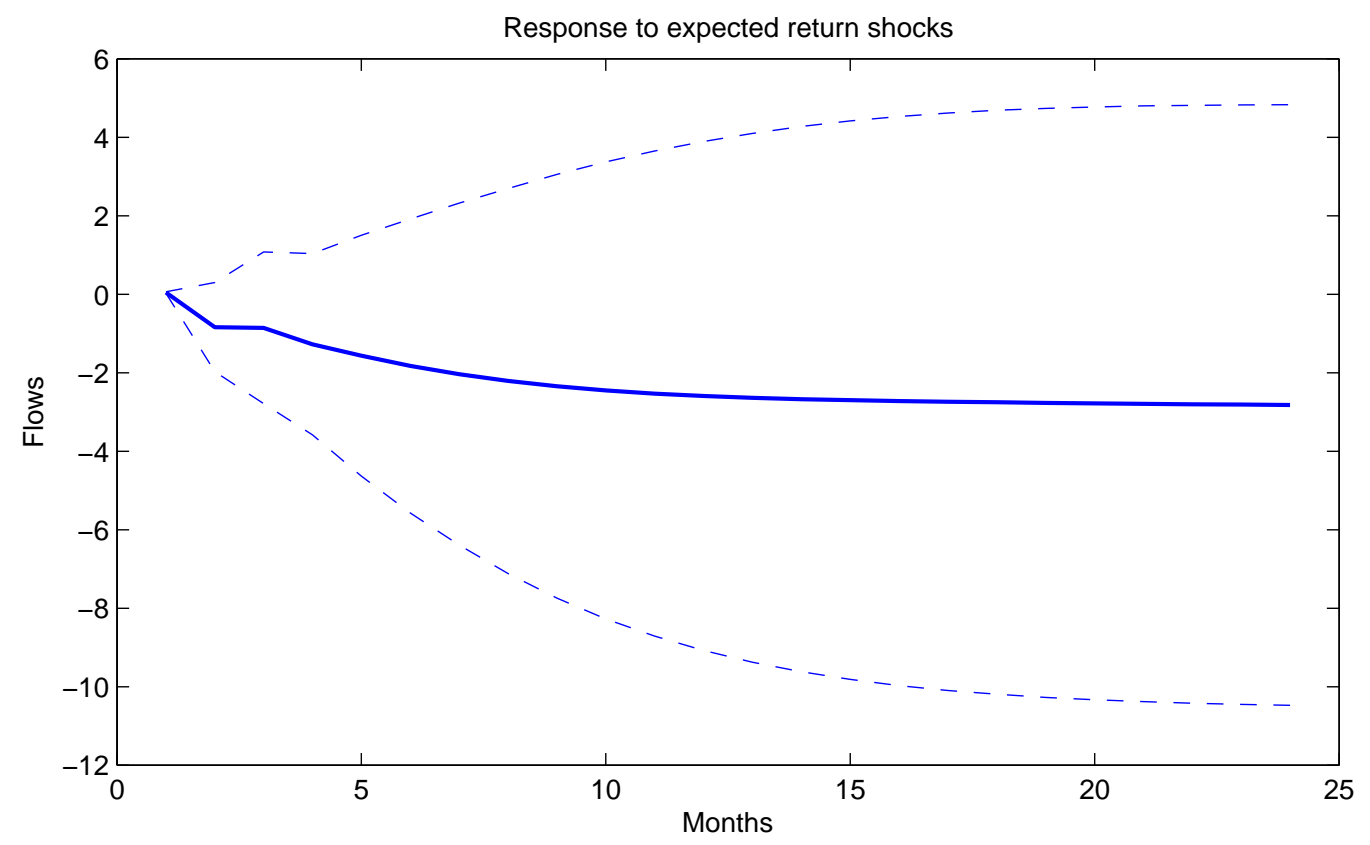


Figure 7. Impulse Response Function of Portfolio Bond Flows to an Excess Return Shock.

This figure shows the cumulated response of bond flows to one standard deviation shock to excess returns. The response is shown at different return horizons (horizontal axis, scale in weeks). The solid line is the response of cumulated bond flows, while the dashed lines display 2 standard deviations bounds estimated using the delete- 1 jackknife method. Data pool emerging markets and developed economies together.

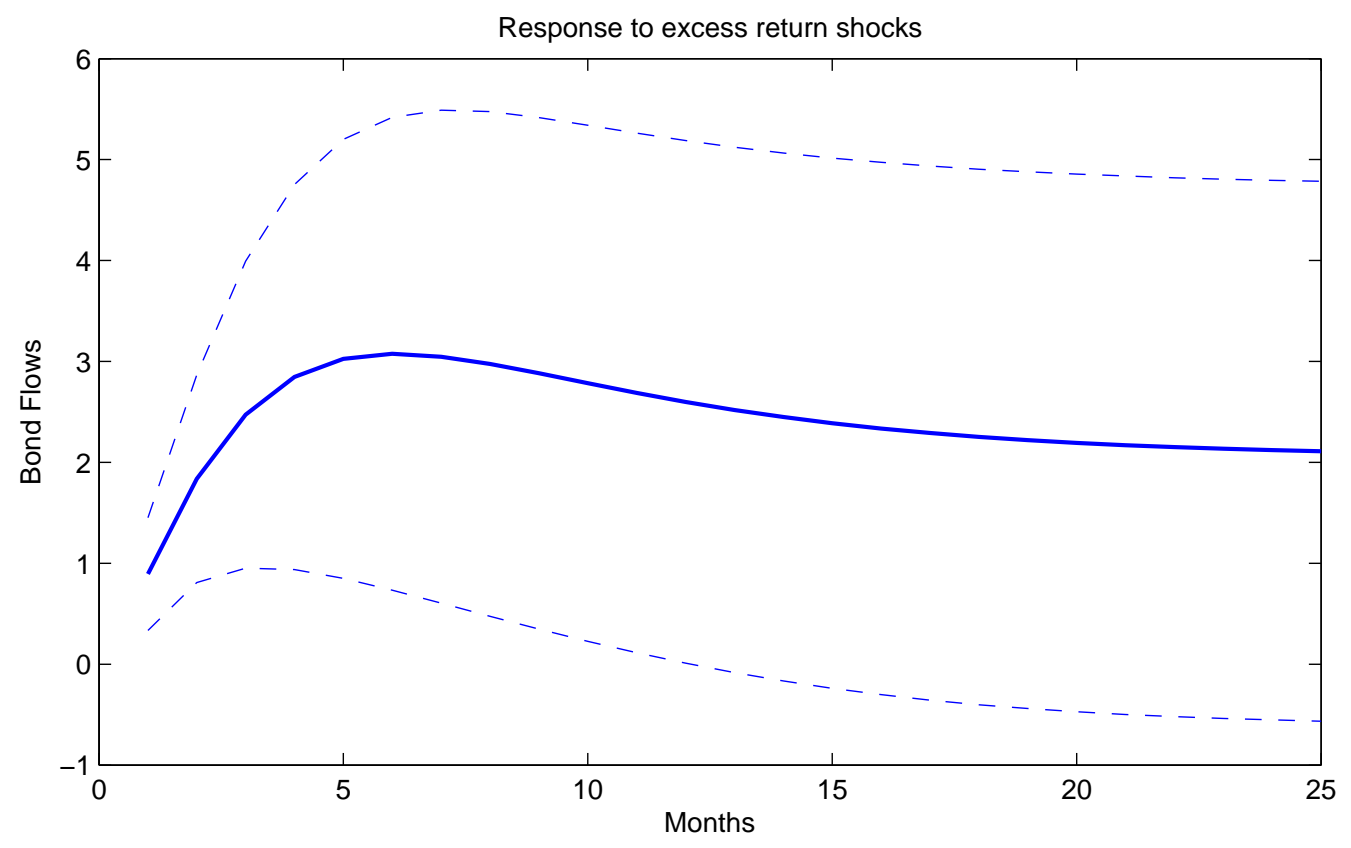


Figure 8. Impulse Response Function of Bonds Excess Return to a Bond Flow Shock.

This figure shows the cumulated response of bond excess returns to a one standard deviation shock to bond flows. The response is shown at different return horizons (horizontal axis, scale in weeks). The solid line is the response of cumulated bond excess returns, while the dashed lines display 2 standard deviations bounds estimated using the delete- 1 jackknife method. Data pool emerging markets and developed economies together.

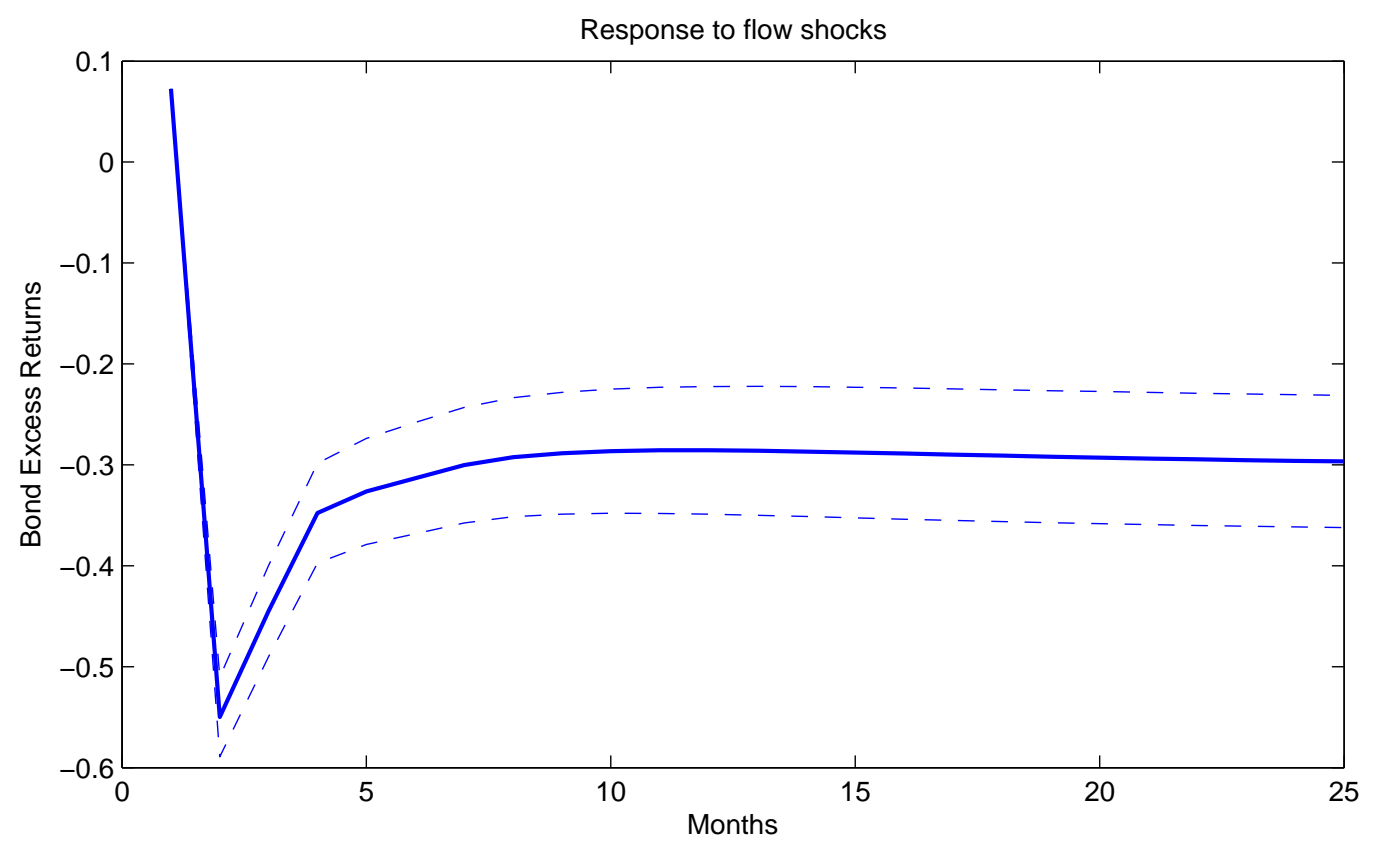


Figure 9. Impulse Response Function of Portfolio Bond Flows to a Negative Expected Return Shock.

This figure shows the cumulated response of bond flows to negative expected returns shock. The shock is induced setting the VAR error vector to a constrained maximum likelihood value, imposing the constraint that excess return shock equals one standard deviations and that the expected inflation shock is zero. The response is shown at different return horizons (horizontal axis, scale in weeks). The solid line is the response of cumulated equity flows, while the dashed lines display 2 standard deviations bounds estimated using the delete- 1 jackknife method. Data pool emerging markets and developed economies together

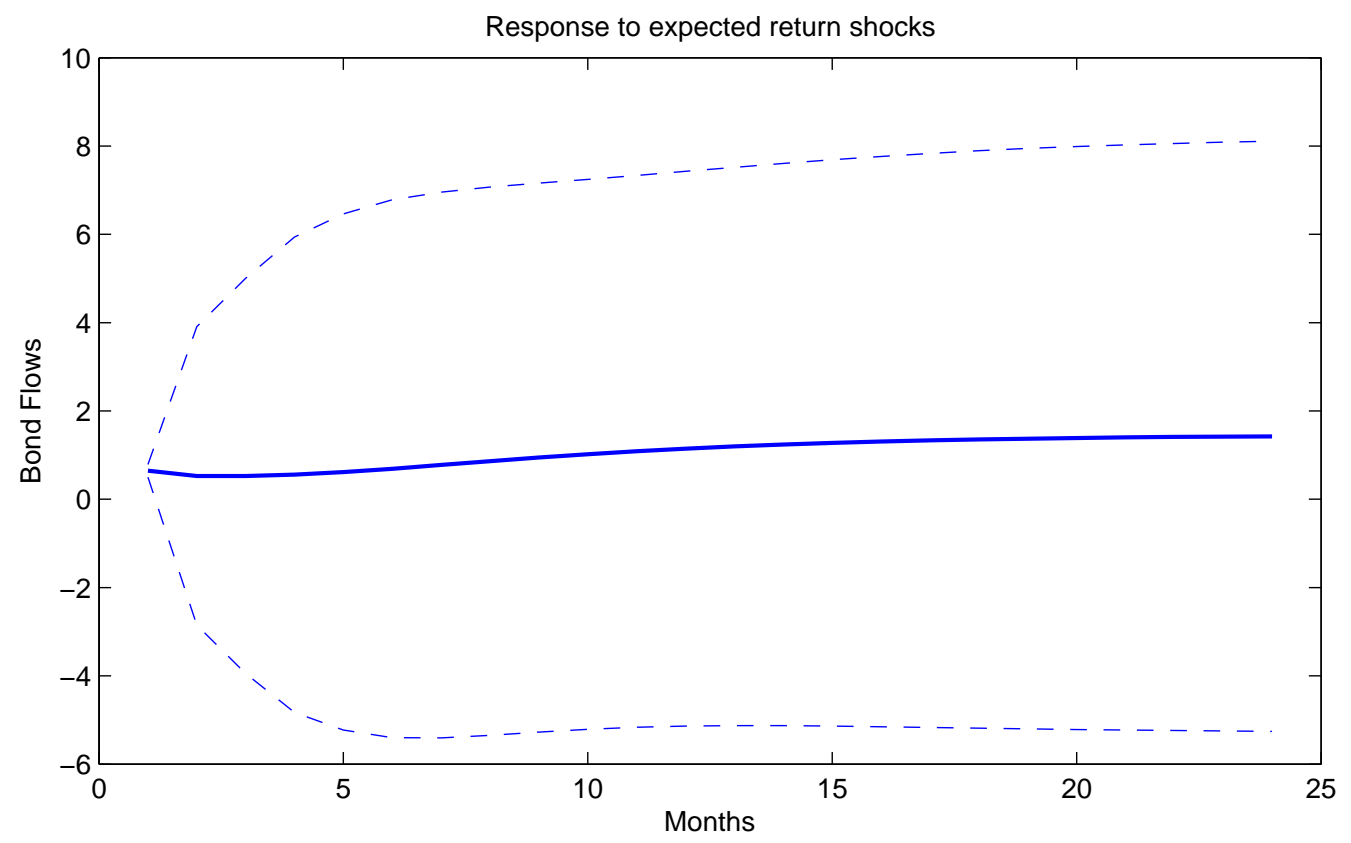


Table 1. Descriptive Statistics.

The table reports descriptive statistics for international equity and bond fund flows for the sample period of January 2004 to December 2013 for 31 countries. Flows are measured as the ratio of their dollar value to the relevant country's nominal GDP. AC(1) denotes the first-order autocorrelation.

\begin{tabular}{|c|c|c|c|c|c|c|}
\hline & \multicolumn{3}{|c|}{ Equities } & \multicolumn{3}{|c|}{ Bonds } \\
\hline & Mean & St. dev. & $\mathrm{AC}(1)$ & Mean & St. dev. & $\mathrm{AC}(1)$ \\
\hline Austria & 0.018 & 0.024 & 0.204 & 0.012 & 0.019 & 0.463 \\
\hline Belgium & 0.016 & 0.022 & 0.551 & 0.013 & 0.020 & 0.451 \\
\hline Canada & 0.035 & 0.049 & 0.265 & 0.035 & 0.044 & 0.620 \\
\hline Czech Republic & 0.025 & 0.039 & 0.381 & 0.007 & 0.011 & 0.616 \\
\hline Denmark & 0.022 & 0.031 & 0.295 & 0.019 & 0.027 & 0.627 \\
\hline Finland & 0.033 & 0.045 & 0.544 & 0.012 & 0.018 & 0.590 \\
\hline France & 0.028 & 0.037 & 0.564 & 0.008 & 0.011 & 0.598 \\
\hline Germany & 0.036 & 0.054 & -0.064 & 0.012 & 0.016 & 0.726 \\
\hline Greece & 0.014 & 0.023 & 0.561 & 0.007 & 0.013 & 0.465 \\
\hline Hong Kong & 0.194 & 0.268 & 0.448 & 0.016 & 0.023 & 0.743 \\
\hline Hungary & 0.044 & 0.075 & 0.347 & 0.069 & 0.086 & 0.788 \\
\hline India & 0.045 & 0.058 & 0.356 & 0.002 & 0.002 & 0.739 \\
\hline Indonesia & 0.028 & 0.035 & 0.509 & 0.020 & 0.028 & 0.547 \\
\hline Ireland & 0.022 & 0.029 & 0.586 & 0.028 & 0.039 & 0.727 \\
\hline Italy & 0.011 & 0.015 & 0.563 & 0.013 & 0.018 & 0.642 \\
\hline Japan & 0.043 & 0.061 & 0.703 & 0.008 & 0.011 & 0.580 \\
\hline Korea & 0.066 & 0.085 & 0.476 & 0.011 & 0.014 & 0.795 \\
\hline Malaysia & 0.055 & 0.076 & 0.253 & 0.038 & 0.048 & 0.773 \\
\hline Mexico & 0.028 & 0.036 & 0.313 & 0.025 & 0.032 & 0.782 \\
\hline New Zealand & 0.004 & 0.006 & 0.489 & 0.030 & 0.036 & 0.813 \\
\hline Norway & 0.022 & 0.029 & 0.587 & 0.016 & 0.020 & 0.760 \\
\hline Philippines & 0.021 & 0.029 & 0.535 & 0.037 & 0.050 & 0.671 \\
\hline Russia & 0.049 & 0.065 & 0.281 & 0.014 & 0.017 & 0.726 \\
\hline Singapore & 0.100 & 0.138 & 0.517 & 0.016 & 0.022 & 0.693 \\
\hline South Africa & 0.066 & 0.089 & 0.423 & 0.034 & 0.043 & 0.787 \\
\hline Spain & 0.016 & 0.021 & 0.622 & 0.008 & 0.017 & 0.535 \\
\hline Sweden & 0.036 & 0.047 & 0.500 & 0.023 & 0.036 & 0.565 \\
\hline Switzerland & 0.118 & 0.176 & 0.080 & 0.017 & 0.040 & -0.199 \\
\hline Thailand & 0.060 & 0.082 & 0.385 & 0.011 & 0.016 & 0.730 \\
\hline United Kingdom & 0.051 & 0.065 & 0.574 & 0.015 & 0.019 & 0.553 \\
\hline
\end{tabular}


Table 2. Variance Decomposition.

The table reports the contribution of return components, as implied by the VAR, to the variance of the unexpected returns of international bond and equity markets. The table shows the variances and covariances of these components, normalised by the variance of the unexpected excess returns. Results displayed in the table refer to the period running from January 2004 to December 2013. Standard errors are calculated with the delete-1 jackknife method and reported within parentheses.

\begin{tabular}{|c|c|c|c|c|c|c|c|c|c|c|}
\hline & \multicolumn{10}{|c|}{ Panel A: Equities } \\
\hline & $\operatorname{var}\left(\tilde{f}_{d}\right)$ & $\operatorname{var}\left(\tilde{f}_{f}\right)$ & $\operatorname{var}\left(\tilde{f}_{q}\right)$ & $\operatorname{var}\left(\tilde{f}_{r}\right)$ & $-2 \operatorname{cov}\left(\tilde{f}_{d}, \tilde{f}_{f}\right)$ & $-2 \operatorname{cov}\left(\tilde{f}_{d}, \tilde{f}_{q}\right)$ & $-2 \operatorname{cov}\left(\tilde{f}_{d}, \tilde{f}_{r}\right)$ & $2 \operatorname{cov}\left(\tilde{f}_{f}, \tilde{f}_{q}\right)$ & $2 \operatorname{cov}\left(\tilde{f}_{f}, \tilde{f}_{r}\right)$ & $2 \operatorname{cov}\left(\tilde{f}_{r}, \tilde{f}_{q}\right)$ \\
\hline \multirow[t]{2}{*}{ All } & 1.518 & 0.425 & 0.000 & 0.004 & -0.989 & -0.001 & 0.043 & 0.000 & -0.001 & 0.000 \\
\hline & $(0.930)$ & $(0.344)$ & $(0.000)$ & $(0.003)$ & $(1.258)$ & $(0.001)$ & $(0.075)$ & $(0.001)$ & $(0.046)$ & $(0.000)$ \\
\hline \multirow[t]{2}{*}{ Emerging Markets } & 1.508 & 0.312 & 0.000 & 0.006 & -0.870 & -0.001 & 0.041 & 0.000 & 0.004 & 0.000 \\
\hline & $(0.751)$ & $(0.300)$ & $(0.000)$ & $(0.006)$ & $(0.897)$ & (0.001) & $(0.127)$ & $(0.000)$ & $(0.109)$ & $(0.000)$ \\
\hline \multirow[t]{4}{*}{ Advanced Economies } & 1.766 & 0.637 & 0.000 & 0.004 & -1.453 & -0.002 & 0.038 & 0.001 & 0.009 & 0.000 \\
\hline & $(1.049)$ & $(0.451)$ & $(0.000)$ & $(0.003)$ & $(1.462)$ & $(0.001)$ & $(0.079)$ & $(0.001)$ & $(0.050)$ & $(0.000)$ \\
\hline & \multicolumn{10}{|c|}{ Panel B: Bonds } \\
\hline & $\operatorname{var}\left(\tilde{x}_{\pi}\right)$ & $\operatorname{var}\left(\tilde{x}_{x}\right)$ & $\operatorname{var}\left(\tilde{x}_{q}\right)$ & $\operatorname{var}\left(\tilde{x}_{r}\right)$ & $2 \operatorname{cov}\left(\tilde{x}_{\pi}, \tilde{x}_{x}\right)$ & $2 \operatorname{cov}\left(\tilde{x}_{\pi}, \tilde{x}_{q}\right)$ & $2 \operatorname{cov}\left(\tilde{x}_{\pi}, \tilde{x}_{r}\right)$ & $2 \operatorname{cov}\left(\tilde{x}_{x}, \tilde{x}_{q}\right)$ & $2 \operatorname{cov}\left(\tilde{x}_{x}, \tilde{x}_{r}\right)$ & $2 \operatorname{cov}\left(\tilde{x}_{r}, \tilde{x}_{q}\right)$ \\
\hline \multirow[t]{2}{*}{ All } & 0.755 & 0.062 & 0.000 & 0.003 & 0.192 & -0.001 & -0.019 & 0.000 & 0.007 & 0.000 \\
\hline & $(0.149)$ & $(0.079)$ & $(0.000)$ & $(0.002)$ & $(0.161)$ & $(0.000)$ & $(0.023)$ & $(0.000)$ & $(0.022)$ & $(0.000)$ \\
\hline \multirow[t]{2}{*}{ Emerging Markets } & 0.893 & 0.048 & 0.000 & 0.006 & 0.043 & -0.001 & 0.015 & 0.000 & -0.004 & 0.000 \\
\hline & $(0.260)$ & $(0.104)$ & $(0.000)$ & $(0.006)$ & $(0.321)$ & (0.001) & $(0.047)$ & (0.001) & $(0.047)$ & $(0.000)$ \\
\hline \multirow[t]{2}{*}{ Advanced Economies } & 0.853 & 0.136 & 0.000 & 0.003 & 0.029 & 0.000 & -0.026 & 0.000 & 0.006 & 0.000 \\
\hline & $(0.286)$ & $(0.160)$ & $(0.000)$ & $(0.002)$ & $(0.423)$ & $(0.000)$ & $(0.037)$ & $(0.000)$ & $(0.028)$ & $(0.000)$ \\
\hline
\end{tabular}




\section{Table 3. Contribution of components using linear regressions.}

The table reports the contribution of return components, as implied by the VAR, to the variance of the unexpected returns of international bond and equity markets. The table shows the $\mathrm{R}^{2}$ values in regressions of unexpected excess returns on each of the orthogonalised components. We orthogonalise each of the components using a Cholesky decomposition. In the decomposition, equity return components are ordered as follows: dividend shocks $\tilde{f}_{d}$, real rate shocks $\tilde{f}_{r}$, exchange rate shocks $\tilde{f}_{q}$, and expected return shocks $\tilde{f}_{f}$. Bond return components are ordered as follows: inflation shocks $\tilde{x}_{\pi}$, real rate shocks $\tilde{x}_{r}$, exchange rate shocks $\tilde{x}_{q}$, and expected return shocks $\tilde{x}_{x}$. Results displayed in the table refer to the period running from January 2004 to December 2013. Standard errors are calculated with the delete- 1 jackknife method and reported within parentheses.

\begin{tabular}{lrrrr}
\hline & \multicolumn{4}{c}{ Panel A: Equities } \\
\cline { 2 - 5 } & $\tilde{f}_{d}$ & $\tilde{f}_{r}$ & $\tilde{f}_{q}$ & $\tilde{f}_{f}$ \\
\hline All & 0.728 & 0.033 & 0.003 & 0.236 \\
& $(0.095)$ & $(0.066)$ & $(0.012)$ & $(0.092)$ \\
Emerging Markets & 0.799 & 0.028 & 0.005 & 0.166 \\
& $(0.277)$ & $(0.223)$ & $(0.017)$ & $(0.088)$ \\
Advanced Economies & 0.631 & 0.076 & 0.006 & 0.285 \\
& $(0.128)$ & $(0.111)$ & $(0.026)$ & $(0.136)$ \\
& & & & \\
& & Panel B: Bonds & \\
\cline { 2 - 5 } All & $\tilde{x}_{\pi}$ & $\tilde{x}_{r}$ & $\tilde{x}_{q}$ & $\tilde{x}_{x}$ \\
Emerging Markets & 0.939 & 0.020 & 0.002 & 0.038 \\
& $(0.104)$ & $(0.064)$ & $(0.018)$ & $(0.056)$ \\
Advanced Economies & 0.952 & 0.001 & 0.009 & 0.035 \\
& $(0.118)$ & $(0.046)$ & $(0.045)$ & $(0.057)$ \\
& 0.855 & 0.013 & 0.018 & 0.112 \\
& $(0.169)$ & $(0.057)$ & $(0.046)$ & $(0.129)$ \\
\hline
\end{tabular}


Table 4. Relations between Portfolio Flows and Returns in International Equity Markets.

The table reports scaled covariances between equity flow and return news as implied by the VAR. Each cell contains estimates of the covariances between the elements indicated in the row and column headings. We pick out the innovations in the variables by postmultiplying the appropriate selection vector by the unexpected shock $u$, the expected short-term (ST) innovation $\Phi(k) u$, the expected long-term (LT) innovation $(\Phi-\Phi(k)) u$, and the total innovation $\Psi u$. We set $k=3$ months. Covariances are scaled by the product of the standard deviation of unexpected excess returns and the standard deviation of unexpected flows to facilitate comparison across the elements of the table. Standard errors are calculated with the delete-1 jackknife method and reported within parentheses.

\begin{tabular}{|c|c|c|c|c|c|c|}
\hline \multirow[b]{2}{*}{ Portfolio flow innovation } & \multicolumn{6}{|c|}{ Return Innovation } \\
\hline & Unexpected Excess Return & Expected ST return & Expected LT return & Real Rates & Exchange Rate & Dividends \\
\hline Unexpected Flow & $\begin{array}{r}0.288 \\
(0.035)\end{array}$ & $\begin{array}{r}0.748 \\
(0.245)\end{array}$ & $\begin{array}{r}-0.474 \\
(0.177)\end{array}$ & $\begin{array}{r}-0.006 \\
(0.026)\end{array}$ & $\begin{array}{r}0.000 \\
(0.000)\end{array}$ & $\begin{array}{r}0.556 \\
(0.307)\end{array}$ \\
\hline Expected ST Flow & $\begin{array}{r}0.746 \\
(0.143)\end{array}$ & $\begin{array}{r}1.733 \\
(0.625)\end{array}$ & $\begin{array}{r}-1.087 \\
(0.394)\end{array}$ & $\begin{array}{r}-0.012 \\
(0.050)\end{array}$ & $\begin{array}{r}0.000 \\
(0.000)\end{array}$ & $\begin{array}{r}1.380 \\
(0.734)\end{array}$ \\
\hline Expected LT Flow & $\begin{array}{r}-0.315 \\
(0.136)\end{array}$ & $\begin{array}{r}-0.705 \\
(0.302)\end{array}$ & $\begin{array}{r}0.523 \\
(0.307)\end{array}$ & $\begin{array}{r}0.008 \\
(0.024)\end{array}$ & $\begin{array}{r}0.000 \\
(0.000)\end{array}$ & $\begin{array}{r}-0.489 \\
(0.260)\end{array}$ \\
\hline Total Flow & $\begin{array}{r}0.718 \\
(0.209)\end{array}$ & $\begin{array}{r}1.776 \\
(0.726)\end{array}$ & $\begin{array}{r}-1.038 \\
(0.377)\end{array}$ & $\begin{array}{r}-0.009 \\
(0.052)\end{array}$ & $\begin{array}{r}0.001 \\
(0.001)\end{array}$ & $\begin{array}{r}1.447 \\
(0.867)\end{array}$ \\
\hline & & Panel B: Advanced & conomies & & & \\
\hline
\end{tabular}

\begin{tabular}{|c|c|c|c|c|c|c|}
\hline \multirow[b]{2}{*}{ Portfolio flow innovation } & \multicolumn{6}{|c|}{ Return Innovation } \\
\hline & Unexpected Excess Return & Expected ST return & Expected LT return & Real Rates & Exchange Rate & Dividends \\
\hline Unexpected Flow & $\begin{array}{r}0.254 \\
(0.066)\end{array}$ & $\begin{array}{r}0.737 \\
(0.288)\end{array}$ & $\begin{array}{r}-0.407 \\
(0.199)\end{array}$ & $\begin{array}{r}-0.009 \\
(0.031)\end{array}$ & $\begin{array}{r}0.000 \\
(0.000)\end{array}$ & $\begin{array}{r}0.575 \\
(0.359)\end{array}$ \\
\hline \multirow[t]{2}{*}{ Expected ST Flow } & 0.653 & 1.584 & -0.846 & -0.010 & 0.000 & 1.382 \\
\hline & $(0.191)$ & $(0.647)$ & $(0.415)$ & $(0.057)$ & $(0.001)$ & $(0.772)$ \\
\hline \multirow[t]{2}{*}{ Expected LT Flow } & -0.160 & -0.432 & 0.413 & 0.010 & 0.000 & -0.168 \\
\hline & $(0.130)$ & $(0.276)$ & $(0.249)$ & $(0.026)$ & $(0.000)$ & $(0.297)$ \\
\hline \multirow[t]{2}{*}{ Total Flow } & 0.747 & 1.889 & -0.839 & -0.009 & 0.001 & 1.789 \\
\hline & $(0.266)$ & $(0.819)$ & $(0.428)$ & $(0.065)$ & $(0.001)$ & $(1.046)$ \\
\hline \multicolumn{7}{|c|}{ Panel C: Emerging Markets } \\
\hline & \multicolumn{6}{|c|}{ Return Innovation } \\
\hline Portfolio flow innovation & Unexpected Excess Return & Expected ST return & Expected LT return & Real Rates & Exchange Rate & Dividends \\
\hline Unexpected Flow & 0.403 & 0.488 & -0.444 & -0.008 & 0.000 & 0.440 \\
\hline \multirow[t]{2}{*}{ Expected ST Flow } & $\begin{array}{r}(0.065) \\
0.954\end{array}$ & $\begin{array}{r}(0.210) \\
1.492\end{array}$ & $\begin{array}{r}(0.108) \\
-1.165\end{array}$ & $\begin{array}{r}(0.016) \\
-0.037\end{array}$ & $\begin{array}{r}(0.000) \\
0.000\end{array}$ & $\begin{array}{r}(0.222) \\
1.245\end{array}$ \\
\hline & $(0.199)$ & $(0.640)$ & $(0.327)$ & $(0.040)$ & $(0.000)$ & $(0.707)$ \\
\hline \multirow[t]{2}{*}{ Expected LT Flow } & -0.492 & -0.624 & 0.558 & 0.017 & 0.000 & -0.541 \\
\hline & $(0.150)$ & $(0.331)$ & $(0.250)$ & $(0.028)$ & $(0.000)$ & $(0.328)$ \\
\hline \multirow[t]{2}{*}{ Total Flow } & 0.865 & 1.357 & -1.051 & -0.027 & 0.000 & 1.144 \\
\hline & $(0.250)$ & $(0.632)$ & $(0.307)$ & $(0.049)$ & $(0.000)$ & $(0.687)$ \\
\hline
\end{tabular}


Table 5. Relations between Portfolio Flows and Returns in International Bond Markets.

The table reports scaled covariances between bond flow and return news as implied by the VAR. Each cell contains estimates of the covariances between the elements indicated in the row and column headings. We pick out the innovations in the variables by postmultiplying the appropriate selection vector by the unexpected shock $u$, the expected short-term (ST) innovation $\Phi(k) u$, the expected long-term (LT) innovation $(\Phi-\Phi(k)) u$, and the total innovation $\Psi u$. We set $k=3$ months. Covariances are scaled by the product of the standard deviation of unexpected excess returns and the standard deviation of unexpected flows to facilitate comparison across the elements of the table. Standard errors are calculated with the delete-1 jackknife method and reported within parentheses.

\begin{tabular}{|c|c|c|c|c|c|c|}
\hline \multicolumn{7}{|c|}{ Panel A: All Countries } \\
\hline \multirow[b]{2}{*}{ Portfolio flow innovation } & \multicolumn{6}{|c|}{ Return Innovation } \\
\hline & Unexpected Excess Return & Expected ST return & Expected LT return & Real Rates & Exchange Rate & Inflation \\
\hline \multirow[t]{2}{*}{ Unexpected Flow } & 0.137 & -0.008 & -0.151 & -0.033 & 0.000 & 0.055 \\
\hline & $(0.089)$ & $(0.172)$ & $(0.096)$ & (0.019) & $(0.000)$ & $(0.222)$ \\
\hline \multirow{2}{*}{ Expected ST Flow } & 0.520 & 0.127 & -0.545 & -0.081 & 0.000 & -0.022 \\
\hline & $(0.169)$ & $(0.346)$ & $(0.276)$ & $(0.050)$ & $(0.001)$ & $(0.466)$ \\
\hline \multirow[t]{2}{*}{ Expected LT Flow } & -0.041 & 0.131 & -0.006 & 0.026 & 0.000 & -0.110 \\
\hline & $(0.141)$ & $(0.208)$ & $(0.159)$ & $(0.018)$ & $(0.000)$ & $(0.216)$ \\
\hline \multirow[t]{2}{*}{ Total Flow } & 0.616 & 0.250 & -0.702 & -0.087 & 0.000 & -0.077 \\
\hline & $(0.207)$ & $(0.362)$ & $(0.346)$ & $(0.057)$ & $(0.001)$ & $(0.501)$ \\
\hline
\end{tabular}

Panel B: Advanced Economies

\begin{tabular}{|c|c|c|c|c|c|c|}
\hline \multirow[b]{2}{*}{ Portfolio flow innovation } & \multicolumn{6}{|c|}{ Return Innovation } \\
\hline & Unexpected Excess Return & Expected ST return & Expected LT return & Real Rates & Exchange Rate & Inflation \\
\hline Unexpected Flow & $\begin{array}{r}0.038 \\
(0.074)\end{array}$ & $\begin{array}{r}-0.177 \\
(0.171)\end{array}$ & $\begin{array}{r}-0.061 \\
(0.102)\end{array}$ & $\begin{array}{r}-0.017 \\
(0.022)\end{array}$ & $\begin{array}{r}0.000 \\
(0.000)\end{array}$ & $\begin{array}{r}0.216 \\
(0.210)\end{array}$ \\
\hline \multirow[t]{2}{*}{ Expected ST Flow } & 0.248 & -0.253 & -0.282 & -0.041 & 0.000 & 0.328 \\
\hline & $(0.227)$ & $(0.406)$ & $(0.295)$ & $(0.048)$ & $(0.001)$ & $(0.474)$ \\
\hline \multirow{2}{*}{ Expected LT Flow } & -0.019 & 0.180 & 0.048 & 0.014 & 0.000 & -0.223 \\
\hline & $(0.070)$ & $(0.175)$ & $(0.103)$ & $(0.020)$ & $(0.000)$ & $(0.213)$ \\
\hline \multirow{2}{*}{ Total Flow } & 0.268 & -0.250 & -0.295 & -0.043 & 0.000 & 0.320 \\
\hline & $(0.252)$ & $(0.445)$ & $(0.315)$ & $(0.052)$ & $(0.001)$ & $(0.512)$ \\
\hline \multicolumn{7}{|c|}{ Panel C: Emerging Markets } \\
\hline & \multicolumn{6}{|c|}{ Return Innovation } \\
\hline Portfolio flow innovation & Unexpected Excess Return & Expected ST return & Expected LT return & Real Rates & Exchange Rate & Inflation \\
\hline Unexpected Flow & $\begin{array}{r}0.256 \\
(0.090)\end{array}$ & $\begin{array}{r}0.250 \\
(0.199)\end{array}$ & $\begin{array}{r}-0.274 \\
(0.156)\end{array}$ & $\begin{array}{r}-0.061 \\
(0.035)\end{array}$ & $\begin{array}{r}0.000 \\
(0.000)\end{array}$ & $\begin{array}{r}-0.171 \\
(0.270)\end{array}$ \\
\hline \multirow[t]{2}{*}{ Expected ST Flow } & 0.845 & 0.907 & -0.907 & -0.159 & 0.001 & -0.687 \\
\hline & $(0.251)$ & $(0.560)$ & $(0.381)$ & $(0.094)$ & $(0.001)$ & $(0.712)$ \\
\hline \multirow[t]{2}{*}{ Expected LT Flow } & -0.062 & -0.014 & 0.001 & 0.022 & 0.000 & 0.054 \\
\hline & $(0.180)$ & $(0.178)$ & $(0.223)$ & $(0.032)$ & $(0.000)$ & $(0.168)$ \\
\hline \multirow[t]{2}{*}{ Total Flow } & 1.039 & 1.143 & -1.180 & -0.198 & 0.001 & -0.804 \\
\hline & $(0.359)$ & $(0.731)$ & $(0.560)$ & $(0.131)$ & $(0.002)$ & $(0.925)$ \\
\hline
\end{tabular}




\section{References}

Ahmed, S., Zlate, A., 2013. Capital flows to emerging market economies: A brave new world?, International Finance Discussion Papers, Board of Governors of the Federal Reserve.

Ammer, J., Mei, J., 1996. Measuring international economic linkages with stock market data. The Journal of Finance 51, 1743-1763.

Ang, A., Bekaert, G., 2007. Stock return predictability: Is it there? Review of Financial Studies 20, 651-707.

Bohn, H., Tesar, L. L., 1996. U.S. Equity Investment in Foreign Markets: Portfolio Rebalancing or Return Chasing? American Economic Review 86, 77-81.

Campbell, J. Y., 1991. A variance decomposition for stock returns. The Economic Journal $101,157-179$.

Campbell, J. Y., Ammer, J., 1993. What moves the stock and bond markets? a variance decomposition for long-term asset returns. The Journal of Finance 48, 3-37.

Campbell, J. Y., Polk, C., Vuolteenaho, T., 2010. Growth or Glamour? Fundamentals and Systematic Risk in Stock Returns. Review of Financial Studies 23, 305-344.

Cenedese, G., Payne, R., Sarno, L., Valente, G., 2015. What do stock markets tell us about exchange rates? Review of Finance (forthcoming).

Chen, L., Zhao, X., 2009. Return decomposition. Review of Financial Studies 22, 5213-5249.

Cochrane, J., Piazzesi, M., 2005. Bond risk premia. American Economic Review 95, 138.

Cochrane, J. H., 2008. The dog that did not bark: A defense of return predictability. Review of Financial Studies 21, 1533-1575.

Cochrane, J. H., 2011. Presidential address: Discount rates. The Journal of Finance 66, $1047-1108$. 
Cohen, R. B., Gompers, P. A., Vuolteenaho, T., 2002. Who underreacts to cash-flow news? evidence from trading between individuals and institutions. Journal of Financial Economics 66, 409-462.

Engsted, T., Pedersen, T. Q., Tanggaard, C., 2012a. The log-linear return approximation, bubbles, and predictability. Journal of Financial and Quantitative Analysis 47, 643-665.

Engsted, T., Pedersen, T. Q., Tanggaard, C., 2012b. Pitfalls in VAR based return decompositions: A clarification. Journal of Banking \& Finance 36, 1255-1265.

Engsted, T., Tanggaard, C., 2001. The Danish stock and bond markets: comovement, return predictability and variance decomposition. Journal of Empirical Finance 8, 243-271.

Fratzscher, M., 2011. Capital flows, push versus pull factors and the global financial crisis. NBER Working Papers 17357, National Bureau of Economic Research, Inc.

Froot, K. A., O’Connell, P. G. J., Seasholes, M. S., 2001. The portfolio flows of international investors. Journal of Financial Economics 59, 151-193.

Froot, K. A., Ramadorai, T., 2005. Currency returns, intrinsic value, and institutionalinvestor flows. The Journal of Finance 60, 1535-1566.

Froot, K. A., Ramadorai, T., 2008. Institutional Portfolio Flows and International Investments. Review of Financial Studies 21, 937-971.

Haldane, A. G., 2014. The age of asset management? Speech at the London Business School's Asset Management Conference, London, 04 April 2014.

International Monetary Fund, 2014. How do changes in the investor base and financial deepening affect emerging market economies? Global Financial Stability Report, April.

Jotikasthira, C., Lundblad, C., Ramadorai, T., 2012. Asset Fire Sales and Purchases and the International Transmission of Funding Shocks. Journal of Finance 67, 2015-2050. 
Koijen, R. S., Nieuwerburgh, S. V., 2011. Predictability of returns and cash flows. Annual Review of Financial Economics 3, 467-491.

Kyle, A. S., 1985. Continuous auctions and insider trading. Econometrica 53, 1315-35.

Lakonishok, J., Shleifer, A., Vishny, R. W., 1992. The impact of institutional trading on stock prices. Journal of Financial Economics 32, 23-43.

Lou, D., 2012. A flow-based explanation for return predictability. Review of Financial Studies $25,3457-3489$.

Pesaran, M. H., Smith, R., 1995. Estimating long-run relationships from dynamic heterogeneous panels. Journal of Econometrics 68, 79-113.

Phylaktis, K., Ravazzolo, F., 2002. Measuring financial and economic integration with equity prices in emerging markets. Journal of International Money and Finance 21, 879-903.

Plazzi, A., 2010. International stock return correlation: real or financial integration? a structural present-value approach, UCLA Anderson School Working Paper.

Plazzi, A., Torous, W., Valkanov, R., 2010. Expected returns and expected growth in rents of commercial real estate. Review of Financial Studies 23, 3469-3519.

Raddatz, C., Schmukler, S. L., 2012. On the international transmission of shocks: Microevidence from mutual fund portfolios. Journal of International Economics 88, 357-374.

Rangvid, J., Schmeling, M., Schrimpf, A., 2013. Dividend predictability around the world. Journal of Financial and Quantitative Analysis (forthcoming).

Rapach, D. E., Zhou, G., 2013. Forecasting stock returns. In: Elliott, G., Timmermann, A. (eds.), Handbook of Economic Forecasting, North Holland.

Rapach, D. E., D. E., Strauss, J. K., Zhou, G., G., 2013. International stock return predictability: What is the role of the United States? The Journal of Finance 68, 1633-1662. 
Shao, J., Rao, J. N. K., 1993. Jackknife inference for heteroscedastic linear regression models. Canadian Journal of Statistics 21, 377-395.

Shiller, R. J., Beltratti, A. E., 1992. Stock prices and bond yields: can their comovements be explained in terms of present value models? Journal of Monetary Economics 30, 25-46.

Van Binsbergen, J. H., Koijen, R. S., 2010. Predictive regressions: A present-value approach. Journal of Finance 65, 1439-1471.

Vuolteenaho, T., 2002. What drives firm-level stock returns? Journal of Finance 57, 233-264.

Welch, I., Goyal, A., 2008. A comprehensive look at the empirical performance of equity premium prediction. Review of Financial Studies 21, 1455-1508. 